\title{
Quality of life, firm productivity, and the value of amenities across Canadian cities
}

\author{
David Albouy Department of Economics, University of Michigan \\ Fernando Leibovici Department of Economics, New York \\ University \\ Casey Warman Department of Economics, Dalhousie University
}

Abstract. We estimate quality-of-life and productivity differences across Canada's metropolitan areas in a hedonic general-equilibrium framework. These are based on the estimated willingness-to-pay of heterogeneous households and firms to locate in various cities, which differ in their wage levels, housing costs, and land values. Using 2006 Canadian Census data, our metropolitan quality-of-life estimates are somewhat consistent with popular rankings, yet find Canadians care more about climate and culture. Quality of life is highest in Victoria for anglophones, Montreal for francophones, and Vancouver for allophones, and lowest in more remote cities. Toronto is Canada's most productive city; Vancouver is the overall most valuable city. JEL classification: J61, R1

Qualité de vie, productivité des entreprises, et la valeur des avantages dans les diverses villes canadiennes. On évalue les différences entre la qualité de vie et la productivité des entreprises entre les zones métropolitaines au Canada à l'aide d'un cadre d'analyse d'équilibre général hédonique. Ces métriques sont basées sur l'estimation de la volonté de payer de ménages et d'entreprises hétérogènes pour se localiser dans diverses villes, qui diffèrent tant pour ce qui est des niveaux de salaires, des coûts de l'habitation, et des prix des terrains. A l'aide des données du recensement canadien de 2006, on construit des évaluations de la qualité de vie des diverses zones métropolitaines qui s'arriment convenablement aux ordonnancements en vogue, mais on découvre que les Canadiens portent une attention particulière au climat et à la culture. La qualité de vie est la plus élevée à Victoria pour les anglophones, à Montreal pour les francophones, et à Vancouver

\footnotetext{
Albouy is also affiliated with the NBER. We would like to thank Kevin Milligan, James Milway, Daniel Parent, and participants of seminars at McGill University, Queen's University, Simon Fraser University, the University of British Columbia, and the University of Victoria, and attendees at the 2009 Canadian Economics Association and Western Economics Association Annual Meetings for their help, input, and advice. All mistakes are our own. The authors gratefully acknowledge the financial assistance provided by the Social Sciences and Humanities Research Council of Canada (SSHRC). While the research and analysis are based on data from Statistics Canada, this paper represents the views of the authors and does not necessarily reflect the opinions of Statistics Canada. Email: albouy@umich.edu
} 
pour les allophones, et la plus faible pour les villes éloignées des grands centres. Toronto est la ville la plus productive; Vancouver est généralement la plus appréciée.

\section{Introduction}

Wage and cost-of-living levels vary significantly across Canadian cities and provinces, despite the fact that capital and labour are largely mobile within Canada's borders. Coulombe and Lee (1995) and Coulombe (2000) find that income and price levels converged significantly between 1960 and 1980, but have converged relatively little since then. These persistent differences in wages and prices are most naturally explained by persistent differences in local advantages to households and firms, broadly termed as 'amenities.' To clarify terminology, we say consumption amenities determine an area's overall quality of life (QOL), while production amenities determine an area's overall productivity. The primary goal of this paper is to identify the overall differences in quality-of-life and productivity levels across Canadian cities.

Some places in Canada have undeniable advantages over others. Most Canadians live south, close to the United States border, where the climate is warmer and trading costs are lower than further north. Canadians are acutely aware of regional disparities in natural resource wealth: from oil in Alberta, forests in British Columbia, potash in Saskatchewan, to depleted fish stocks in the Atlantic provinces. Much of the population is concentrated in a handful of large cities, which benefit from sizable agglomeration economies and vast cultural opportunities, but also suffer disproportionately from urban disamenities such as crime, pollution, and congestion. Strong local and provincial governments, as well as differential treatment of regions by the federal government, also lead to geographic differences in public services and taxation.

While some places appear more advantaged than others, much of the population is still located in less advantaged areas. Although heterogeneity in household tastes and production technologies may help explain this, the importance of heterogeneity should not be overstated: most individuals prefer temperatures above -40 , and most firms benefit from low transportation costs. Furthermore, many Canadians are quite mobile over their lifetime and have only limited local attachments (e.g., Bernard, Finnie, and St-Jean 2008).

In this setting, households and firms in areas with less advantageous amenities should be largely compensated by more advantageous local prices. Specifically, households in areas with lower QOL should be compensated through either higher nominal wages or lower costs of living. Firms in less productive areas should be compensated through either lower labour or non-labour costs. This is the essence of the methodology of Rosen (1979) and Roback (1982), which has been used extensively by researchers to measure QOL and productivity differences in the United States (e.g., Blomquist, Berger, and Hoehn 1988; Beeson 
and Eberts 1989; Gyourko and Tracy 1991; Gabriel and Rosenthal 2004; Shapiro 2006; Chen and Rosenthal 2008).

Surprisingly, this popular methodology has never been applied to Canadian data. We explain this theory in section 2, using the framework by Albouy (2008a, $2009 \mathrm{~b}$ ), which realistically incorporates federal taxes and produced non-tradable goods, such as housing. In section 3, we explain how to calibrate this model for Canada, and use the 2006 Census microdata to estimate wage and housing-cost differences across Census Metropolitan Areas (CMAs), so as to infer QOL and productivity differences across CMAs.

Several issues arise in applying the Rosen-Roback framework to Canada. First, while most areas of Canada are mainly English speaking, areas such as Quebec, are predominantly French speaking, while areas such as New Brunswick, are largely bilingual. Different language groups naturally have preferences for different areas, as most would prefer to live where their mother tongue is predominant. Roback (1988) and Beeson (1991) estimate QOL advantages for different groups defined by education groups; we estimate QOL for groups defined by mother tongue, a more predetermined characteristic. We also discuss, for what appears to be the first time, how the model may be aggregated across types and be used to estimate productivity differences between groups.

Second, unionization rates in Canada are still high relative to those of the United States, but vary across regions. This means that some areas may have high real wage levels not because of low amenities, but because of a strong union presence. We find it most plausible to assume that union wage premia do not reflect urban productivity or QOL differences, and use wage estimates purged of unionization effects.

Third, federal and provincial governments play a large role in taxing income and redistributing it through intergovernmental transfers. The role of taxes on residents is dealt with in the model following adjustments in Albouy (2008a, 2009a). It is less clear how the model should accommodate intergovernmental transfers and fiscal disparities due to natural resource wealth, documented in Albouy (2012). Thus, we exclude these from the main analysis, and consider them in alternative results at the end.

According to our estimates in section 4, the CMA with the highest QOL is Victoria, followed by the other British Columbian CMAs of Vancouver, Kelowna, Abbotsford, and then Toronto, Calgary, and Montreal. The rankings for different language groups are rather consistent across CMAs with sufficiently large populations of each: anglophones, francophones, and allophones all seem to prefer Montreal to Ottawa-Hull.

Our estimates of firm productivity in tradables, also the first of their kind for Canada, reveal Toronto to be the most productive CMA, followed by Calgary, Oshawa, Vancouver, and Ottawa-Hull. While the QOL of anglophones in Montreal appears to be almost the same as in Toronto, their productivity is lower than that of anglophones in Kingston. This is consistent with the reasoning in 
Albouy (2008b) that, since 1970, anglophones fled Montreal more from a loss of jobs than from a loss of amenities.

Under the assumption that there are no sizable differences in unobservable firm productivity in non-tradables, we create aggregate measures of land rents and the combined value of urban amenities to households and firms. According to this metric, the most valuable CMA per hectare is Vancouver, followed by Victoria, Toronto, Calgary, Kelowna, and Montreal.

While QOL greatly interests policy-makers and the general population, published indicators of QOL for Canadian cities consist broadly of weighted sums of arbitrarily chosen amenities, with ad hoc weights. Such indices are found in Cities Ranked \& Rated, Places Rated Almanac, and Mercer's Quality-of-Living Reports. These are informative only to the extent that the ad hoc weighting schemes used in their calculations actually reflect peoples' values. The willingness-to-pay methodology implemented here instead makes use of data on local wages and housing costs to identify the aggregate value of the different amenities. We show in section 5 that our estimates are generally in line with the popular rankings, but that households put more weight on climate and arts and culture. Finally, in section 6 we consider how our estimates would be influenced by including intergovernmental transfers, alternative price data from the CPI, or using housing-cost data from rental units alone. ${ }^{1}$

\section{Theoretical model of spatial equilibrium}

Quality-of-life and productivity differences across cities are measured from wage and housing-cost differences across cities using the theoretical framework of Albouy (2008a, 2009a). This framework builds upon that of Rosen (1979) and Roback (1982), but also accounts for non-labour income, housing production, cost-of-living differences from non-housing sources, and inequalities in both federal and provincial taxation. Furthermore, like Roback (1988) and Beeson (1991) we account for multiple household types, but in a richer setting that deals with aggregation and productivity measurement.

1 To our knowledge, the only attempt to measure QOL across Canadian cities in an economic framework, distantly related to the one here, is Giannias (1998), who does so for 13 cities using 1981 data. This work measures QOL according to how housing costs co-vary with six amenity measures, controlling for three housing characteristics, and assuming that incomes do not depend on where households locate. This methodology depends on a highly parametric model with strict normality assumptions and a linear housing price equation, which departs from more established log-linear specifications. Our model instead endogenizes wage differences, controls for many worker and housing characteristics, is independent of any set of chosen amenities, and is illustrated through graphs mapping the relationship of wage and housing-cost differences to QOL and productivity differences. Furthermore, our analysis covers all 33 currently defined Census Metropolitan Areas (CMAs), which we sometimes refer to as 'cities,' as well as the non-metropolitan areas of Canada, organized by province or territory. 


\subsection{Setup}

The national economy contains many cities, indexed by $j$, which trade with each other and share several types of mobile households, indexed by $g \in\{1, \ldots, G\}$. The population in city $j$ is denoted as the vector $\mathbf{N}^{j}=\left(N_{1}^{j}, \ldots, N_{G}^{j}\right)$. Each household consumes a numeraire traded good, $x$, and a group-specific non-traded local good, ${ }^{2} y_{g}$, with local price, $p_{g}^{j}$, which varies by city and type. This accounts for the possibility that households may consume housing in different neighbourhoods or goods produced disproportionately by their own type (e.g., anglophones in Montreal live in certain neighbourhoods and are more likely to consume services produced by other anglophones). In the empirical implementation of the model, the price of local goods for type $g$ is equated with the cost of housing paid by that type. ${ }^{3}$

Firms produce traded and local goods out of land, capital, and labour. Within a city, factors receive the same payment in either sector. Land, $L$, within each city is homogeneous and immobile, and is paid a city-specific price $r^{j}$; each city's land supply, $L^{j}(r)$, may depend positively on $r^{j}$, with a finite elasticity $\varepsilon_{L, r}^{j} \in[0 . \infty) .{ }^{4}$ Capital, $K$, is costlessly mobile across cities, and is paid the price $\bar{\imath}$ everywhere: this price may be set either nationally or internationally, although for simplicity net foreign asset holdings are set to zero. Households of each type $g, N_{g}$, are perfectly mobile within the country, have identical tastes and endowments, and each supplies a single unit of labour. Because households care about local prices and QOL, wages, denoted by the vector $\mathbf{w}^{j}=\left(w_{g}^{j}, \ldots, w_{G}^{j}\right)$, may vary across cities. The national number of worker-households is fixed at $\mathbf{N}^{T O T}=$ $\left(N_{1}^{T O T}, \ldots, N_{G}^{T O T}\right)$, so that the sum of populations across cities $\sum_{j} \mathbf{N}^{j}=\mathbf{N}^{T O T}$. Households of each type own identical diversified portfolios of land and capital, which pay an income $R_{g}$ from land and $I_{g}$ from capital, regardless of the city they live in. Gross income, $m_{g}^{j} \equiv R_{g}+I_{g}+w_{g}^{j}$, varies across cities only as wages vary. Out of this income households pay a federal income tax of $\tau\left(m_{g}\right)$, which is redistributed in lump-sum transfers, $T_{g}^{j}$, which may vary by city. For expositional ease, provincial taxes are discussed in the online technical appendix. ${ }^{5}$

2 The productivity differences in non-traded goods may be quite variable. Without separate data on land values across cities, it is nearly impossible to identify them. However, Albouy (2009b) shows that this does not bias the quality-of-life estimates and has only a minor bias on the trade-productivity estimates for reasonable calibrations.

3 As shown in Roback (1980), the use of a single traded good may be used to approximate the case of multiple goods. Factor-price equalization, as in the Hecksher-Ohlin model of trade, does not occur, because factors are mobile and many cities may specialize in the production of fewer tradable goods than factors. Furthermore, non-housing goods may be considered to be a combination of traded goods and non-housing local goods.

4 The assumption of homogeneous land is used for simplicity, as we do not directly observe land values in any of our datasets. As discussed in Albouy and Lue (2011), land values within CMAs may differ significantly because of local amenities as well as transportation costs. Our estimates may be taken as an average of the value of land within a city. Our QOL estimates implicitly include a penalty for areas with higher transportation costs.

5 The technical appendix is available from the CJE online archive at cje.economics.ca. 
Cities differ in two types of attributes: quality of life, which raises household utility and is given by the vector $\mathbf{Q}^{j}=\left(Q_{1}^{j}, \ldots, Q_{G}^{j}\right)$, and productivity in the traded-good sector, which varies by factor and is given by the vector $\mathbf{A}^{j}=\left(A_{1}^{j}, \ldots, A_{G}^{j}, A_{L}^{j}, A_{K}^{j}\right)$. These attributes, in turn, depend on a vector of amenities, $\mathbf{Z}^{j}=\left(Z_{1}^{j}, \ldots, Z_{\bar{k}}^{j}\right)$, natural or artificial, according to some unknown functions $\mathbf{Q}^{j}=\widetilde{Q}\left(\mathbf{Z}^{j}\right)$ and $\mathbf{A}^{j}=\widetilde{A}\left(\mathbf{Z}^{j}\right)$. For a consumption amenity, for example, safety or clement weather, $\partial \widetilde{Q}_{g} / \partial Z_{k}>0$; for a production amenity, navigable water or agglomeration economies, $\partial \widetilde{A}_{g} / \partial Z_{k}>0$. It is possible that a single amenity affects both productivity and QOL. ${ }^{6}$

Household preferences are modelled by a utility function $U_{g}\left(x, y_{g} ; Q_{g}\right)$, which is quasi-concave over $x$ and $y_{g}$, and increasing in $Q_{g}$. The expenditure function for a worker of type $g$ in city $j$ is $e_{g}\left(p_{g}^{j}, u_{g} ; Q_{g}^{j}\right) \equiv \min _{x, y}\left\{x+p_{g}^{j} y: U_{g}\left(x, y ; Q_{g}^{j}\right) \geq\right.$ $\left.u_{g}\right\} . Q_{g}$ is normalized so that $e_{g}\left(p_{g}^{j}, \bar{u}_{g} ; Q_{g}^{j}\right)=e_{g}\left(p_{g}^{j}, \bar{u}_{g}\right) / Q_{g}^{j}$, where $e_{g}\left(p_{g}^{j}, \bar{u}_{g}\right) \equiv$ $e_{g}\left(p_{g}^{j}, \bar{u}_{g} ; 1\right)$, meaning that a $1 \%$ increase in $Q_{g}$ is equivalent to a $1 \%$ increase in disposable income. Since households are fully mobile, their utility must be the same across all the cities that they inhabit. Thus, the after-tax income households earn in each city should equal the expenditure needed to obtain the common level of utility, $\bar{u}_{g}$, given local prices and QOL: ${ }^{7}$

$$
e_{g}\left(p_{g}^{j}, \bar{u}_{g} ; Q_{g}^{j}\right)=m_{g}^{j}-\tau\left(m_{g}^{j}\right)+T_{g}^{j}
$$

for all types $g$ and cities $j$ where $N_{g}^{j}>0$.

All input and goods markets are perfectly competitive, and firms produce under constant returns to scale. Let the vector $\mathbf{A}_{N}^{j}=\left(A_{1}^{j}, \ldots, A_{G}^{j}\right)$ denote only labour productivity, the vector $\mathbf{N}_{X}^{j}=\left(N_{1 X}^{j}, \ldots, N_{G X}^{j}\right)$ denote labour used to produce the traded good, and $\mathbf{N}_{Y g}^{j}=\left(N_{Y g 1}^{j}, \ldots, N_{Y g G}^{j}\right)$ denote the labour used to produce each local good $g$, with $\mathbf{N}_{Y}^{j}=\sum_{g} \mathbf{N}_{Y g}^{j}$; similar notation is used for land and capital, with $L_{Y}^{j}=\sum_{g} L_{Y g}^{j}$, and so on. Then the production functions of representative traded-good and local-good firms are $X^{j}=F_{X}\left(\mathbf{A}_{N}^{j} \cdot \mathbf{N}_{X}^{j}, A_{L}^{j} L_{X}^{j}, A_{K}^{j} K_{X}^{j}\right)$ and $Y_{g}^{j}=F_{Y g}\left(\mathbf{N}_{Y g}^{j}, L_{Y g}^{j}, K_{Y g}^{j}\right)$, for all $g$, where $F_{X}$ and $F_{Y g}$ are concave and exhibit constant returns to scale. All factors are fully employed: $\mathbf{N}_{X}^{j}+\mathbf{N}_{Y}^{j}=\mathbf{N}^{j}, L_{X}^{j}+L_{Y}^{j}=L^{j}$ and $K_{X}^{j}+K_{Y}^{j}=K^{j}$. Unit

6 It is worth noting that amenities may be endogenous to quantities in the model, and that this poses different problems when values are measured by using comparative statics. For example, an increase in population, $N^{j}$, may lead to greater pollution, lowering $Q^{j}$. If a city were to receive a theme-park, improving $Q$, this would raise $N$, raising pollution and indirectly decreasing $Q$. The value of the theme-park could be measured empirically by controlling for pollution, although the value when accounting for pollution externalities should not control for pollution. Both direct and indirect effects of amenities have to be taken into account when using comparative statics to determine the causal effect of an amenity on the attributes and prices in a city.

7 The mobility condition need not apply to all households, but only to a sufficiently large subset of mobile marginal households. 
cost in the traded-good sector is $c_{X}\left(\mathbf{w}^{j}, r^{j}, \vec{\imath} ; A^{j}\right) \equiv \min _{\mathbf{N}, L, K}\left\{\mathbf{w}^{j} \cdot \mathbf{N}+r^{j} L+\vec{\imath} K\right.$ : $\left.F_{X}\left(\mathbf{A}_{N}^{j} \cdot \mathbf{N}_{X}^{j}, A_{L}^{j} L_{X}^{j}, A_{K}^{j} K_{X}^{j}\right)=1\right\}$. As markets are competitive, firms make zero profits in equilibrium, so that

$$
c_{X}\left(\mathbf{w}^{j}, r^{j}, \vec{i} ; \mathbf{A}^{j}\right)=1
$$

in all cities $j$. A symmetric definition holds for the unit costs in the local-good sectors, $c_{Y g}$, except that, because of data limitations, we assume uniform productivity for all $g$ and $j$

$$
c_{Y g}\left(\mathbf{w}^{j}, r^{j}, \vec{\imath}\right)=p_{g}^{j}
$$

for all types $g$ and cities $j$ where $N_{g}^{j}>0$.

Scalars with superscripts $j$ refer to city-specific values, while those without superscripts refer to national averages. The share of all income that goes to households of type $g$ is denoted $\mu_{g} \equiv N_{g}^{T O T} m_{g} /\left(\sum_{g^{\prime}} N_{g^{\prime}}^{T O T} m_{g^{\prime}}\right)$, with $\mu=\left(\mu_{1}, \ldots, \mu_{G}\right)$; within a city, the comparable notation is $\boldsymbol{\mu}^{j}=\left(\mu_{1}^{j}, \ldots, \mu_{G}^{j}\right)$. For households, denote the average share of gross expenditures spent on traded goods and local goods as $s_{x g} \equiv x_{g} / m_{g}$ and $s_{y g} \equiv p_{g} y_{g} / m_{g}$; denote the shares of income received from labour, land, and capital income as $s_{w g} \equiv w_{g} / m_{g}, s_{R g} \equiv R_{g} / m_{g}$, and $s_{I g} \equiv I_{g} / m_{g}$. Each share may be put into a vector of the form $\mathbf{s}_{x}=\left(s_{x 1}, \ldots, s_{x G}\right)$. Using averages, it is possible to write the aggregate expenditure shares, $s_{y}=\boldsymbol{\mu} \cdot \mathbf{s}_{y}$, and income shares $s_{w}=\boldsymbol{\mu} \cdot \mathbf{s}_{w}$, and so on. For firms producing traded goods, denote the cost shares of labour, land, and capital as $\theta_{N g} \equiv w_{g} N_{X g} / X, \theta_{L} \equiv r L_{X} / X$, and $\theta_{K} \equiv \bar{\imath} K_{X} / X$, with $\boldsymbol{\theta}_{N}=\left(\theta_{N 1}, \ldots, \theta_{N G}\right)$, and the overall labour-cost share $\theta_{N}=\sum_{g} \theta_{N g}$. Denote similarly defined cost shares in the local-good sector $\boldsymbol{\phi}_{g N}$, $\phi_{g L}$, and $\phi_{g K}$, with the cost-share of local good $g$ from labour type $g^{\prime}$ given by $\phi_{g N g^{\prime}}$, so that $\boldsymbol{\phi}_{g N}=\left(\phi_{g N 1}, \ldots, \phi_{g N G}\right)$.

\subsection{Measuring quality of life and productivity}

We begin by considering the case in which there is only one type of household, and productivity is factor neutral; that is, $\mathbf{A}_{N}^{j}=\mathbf{A}_{L}^{j}=\mathbf{A}_{K}^{j}=\mathbf{A}^{j}$. We continue with an explanation of multiple types, showing under what assumptions we may aggregate results to reproduce the single-type case.

\subsubsection{Single household type}

To analyze the effect of city attributes on prices we log-linearize the equilibrium conditions (1), (2), and (3) around the national average. Thus, for any variable $z, \hat{z}^{j}=\ln z^{j}-\ln \bar{z} \cong\left(z^{j}-\bar{z}\right) / \bar{z}$, approximates the percentage difference in city $j$ of $z$ relative to the geometric average $\bar{z}$, which is the value for a nationally representative city. Log-linearized versions of (1), (2), and (3) describe how prices 
co-vary with city attributes:

$$
\begin{aligned}
& \hat{Q}^{j}=s_{y} \hat{p}_{j}-s_{w}\left(1-\tau^{\prime}\right) \hat{w}^{j}-d T^{j} / m \\
& \hat{A}^{j}=\theta_{N} \hat{w}^{j}+\theta_{L} \hat{r}^{j} \\
& \hat{p}^{j}=\phi_{N} \hat{w}^{j}+\phi_{L} \hat{r}^{j} .
\end{aligned}
$$

These equations are first-order approximations around a nationally representative city, and so the share values are national averages. Equation (4a) measures the QOL differential, $\hat{Q}^{j}$, from how high the cost of living, $s_{y} \hat{p}^{j}$, is relative to after-tax nominal income, $s_{w}\left(1-\tau^{\prime}\right) \hat{w}^{j}$, and transfer differences, expressed as a fraction of income, $d T^{j} / m$. Thus, $\hat{Q}^{j}$ expresses the fraction of income households are willing to pay - or, if negative, to accept - to live in city $j$ relative to a city with an average QOL. Equation (4b) measures the productivity differential, $\hat{A}^{j}$, from how high the labour costs, $\theta_{N} \hat{w}^{j}$, and land costs, $\theta_{L} \hat{r}^{j}$, are in traded-good production. It measures the percentage cost-savings that firms experience from locating in city $j$ relative to the national average. Equation (4c) constrains the local-good price differential, $\hat{p}^{j}$, to equal the labour-cost differential, $\phi_{N} \hat{w}^{j}$, plus the land-cost differential, $\phi_{L} \hat{r}^{j}$. It is safe to assume that local goods are more land intensive and less labour intensive than traded goods, so that $\phi_{L}>\theta_{L}$ and $\theta_{N}>\phi_{N}$.

In practice, wage and local-good price differentials are observable, and so QOL differentials are measurable directly from (4a). Land-rents are generally unobserved, making it difficult to measure productivity directly from (4b). However, by assuming that local-good productivity is the same across cities, it is possible to infer both land-rent and productivity differentials using only data on local-good costs and wages by rearranging equation (4c) and then substituting into (4b):

$$
\begin{aligned}
& \hat{r}^{j}=\frac{1}{\phi_{L}}\left(\hat{p}^{j}-\phi_{N} \hat{w}^{j}\right) \\
& \hat{A}^{j}=\frac{\theta_{L}}{\phi_{L}} \hat{p}^{j}+\left(\theta_{N}-\phi_{N} \frac{\theta_{L}}{\phi_{L}}\right) \hat{w}^{j} .
\end{aligned}
$$

Land rents are inferred in (5) by subtracting off the labour costs $\phi_{N} \hat{w}_{j}$ from $\hat{p}_{j}-$ which in the case of housing could be interpretable as construction costs - and dividing the remainder by the cost share of land, $\phi_{L}$. The productivity measure in (6) is based on nominal wage levels through $\theta_{N} \hat{w}^{j}$ plus the cost share due to land, inferred through local-good prices. The coefficient $\theta_{L} / \phi_{L}>1$ reflects how much more local-good prices must be weighted when they are used to proxy for land values, while the negative term in parentheses removes the double-counting of labour costs in $\hat{p}$. 
The total value of amenity-differences for city $j$ is equal to the QOL differential plus the productivity differential times its share of expenditure

$$
\begin{aligned}
\hat{\Omega}^{j} & =\hat{Q}^{j}+s_{x} \hat{A}^{j} \\
& =\frac{s_{R}}{\phi_{L}} \hat{p}^{j}+\left(\tau^{\prime} s_{w}-\frac{s_{R} \phi_{N}}{\phi_{L}}\right) \hat{w}^{j}-\frac{d T^{j}}{m} .
\end{aligned}
$$

The second equality, expressed in terms of observable variables, results from substituting in (4a) and (4b). Collecting terms, using (5) and simplifying, we obtain that the total amenity differential expresses the social value of land. This is equal to the differential value of private land rents, measured as a percentage of income, plus the fiscal externalities in terms of additional federal taxes paid net of federal transfers received.

$$
\hat{\Omega}^{j}=s_{R} \hat{r}^{j}+\tau^{\prime} s_{w} \hat{w}^{j}-d T^{j} / m .
$$

It is worth noting that if tradable goods are heterogeneous, a higher level of demand for goods produced disproportionately in city $j$ may be conflated with a higher level of productivity. For instance, if the world price for oil is particularly high, and workers in Calgary are concentrated in the oil industry, then the marginal revenue product of workers in Calgary may be relatively high, even if their marginal physical product is not. Thus, $\hat{A}^{j}$ may be interpreted to capture a combination of both real and pecuniary effects.

Furthermore, cities could also vary in their productivity of local goods. As discussed in Albouy (2009b), productivity in local goods cannot be identified without extensive data on land values, which are currently unavailable in Canada. Under our other assumptions, lack of such identification does not affect our measures of quality of life, $\hat{Q}^{j}$; the lack does cause our measures of tradablegood productivity, $\hat{A}^{j}$, to be slightly underestimated in cities where local-good productivity is high. Inferred land values both private, $\hat{r}$, and social, $\hat{\Omega}^{j}$, are more severely underestimated in such cities, but these are peripheral to our analysis. ${ }^{8}$

\subsubsection{Multiple household types and aggregation}

With multiple types, the log-linearized version of the mobility condition (1) is

$$
\hat{Q}_{g}^{j}=s_{y g} \hat{p}_{g}^{j}-s_{w g}\left(1-\tau_{g}^{\prime}\right) \hat{w}_{g}^{j}-d T^{j} / m_{g}
$$

for each group $g$. Note that this requires each group's price and wage differentials, $\hat{p}_{g}^{j}$ and $\hat{w}_{g}^{j}$, but also each group's specific marginal tax rate, $\tau_{g}^{\prime}$, expenditure

8 Higher productivity in non-tradables tends to lower wages and prices by a relatively small amount, and in the same proportion that trade productivity raises them. More generally, the measure of productivity we use strongly reflects higher levels of tradable productivity and, more weakly, lower levels of non-tradable productivity. 
share $s_{y g}$, and income share $s_{w g}$. It is possible to define an aggregate quality-oflife index $\hat{Q}^{j} \equiv \boldsymbol{\mu}^{j} \cdot \hat{\mathbf{Q}}^{j}$ that is consistent with the single-type index in (4a) if we define the aggregate local-good price differential as $\hat{p}^{j} \equiv\left(1 / s_{y}\right) \sum_{g} \mu_{g}^{j} s_{y g} \hat{p}_{g}^{j}$, and the aggregate wage differential as $\hat{w}^{j} \equiv\left(1 / s_{w}\right) \sum_{g} \mu_{g}^{j} s_{w g} \hat{w}_{g}^{j}$, and assume that all groups face the same marginal tax rate $\tau^{\prime}$.

With multiple labour types, the zero-profit condition for tradable-goodproducing firms is $\hat{A}^{j}=\boldsymbol{\theta}_{N} \cdot \hat{\mathbf{w}}^{j}+\theta_{L} \hat{r}^{j}$, where $\hat{A}^{j} \equiv \boldsymbol{\theta}_{N} \cdot \hat{\mathbf{A}}_{N}^{j}+\theta_{L} \hat{A}_{L}^{j}+\theta_{K} \hat{A}_{K}^{j}$, which estimates productivity using the labour-cost measure with $\boldsymbol{\theta}_{N}^{j} \cdot \hat{\mathbf{w}}^{j}$. A potential problem with this approximation is that the local cost shares, $\boldsymbol{\theta}_{N}^{j}$, may vary considerably from the national ones, $\boldsymbol{\theta}_{N}$. But, when each group $g$ 's fraction of total labour costs in city $j, \theta_{N g}^{j} / \theta_{N}$, is proportional to its share of total labour income in city $j$, that is,

$$
\frac{\theta_{N g}^{j}}{\theta_{N}}=\mu_{g}^{j} \frac{s_{w g}}{s_{w}} \quad \text { for all } g
$$

the single wage measure proposed above, $\hat{w}^{j}$, reflects labour costs with local cost shares, $\boldsymbol{\theta}_{N}^{j}$, so that $\theta_{N} \hat{w}^{j}=\boldsymbol{\theta}_{N}^{j} \cdot \hat{\mathbf{w}}^{j}$. Thus, estimates from equation (4b) still measure overall productivity, as before, although they reflect the factors in proportion to how they are used locally, rather than nationally.

In the online technical appendix A.1, we show that, using this same assumption, it is possible to estimate the land-rent differential using equation (6) from aggregate wage and housing-cost differences, using the approximations $\phi_{L}=\left(s_{R}-s_{x} \theta_{L}\right) / s_{y}$ and $\phi_{N}=\left(s_{w}-s_{x} \theta_{N}\right) / s_{y}$. Thus, we can have a feasible estimate of productivity from (6) above that estimates the marginal productivity of land through residential housing. Furthermore, if federal marginal tax rates for groups are the same, then the total value of amenities is still given by (7).

As households are perfectly mobile and each type has homogeneous tastes, we should expect households to sort across CMAs according to their tastes for local amenities. The centrifugal forces of household preferences may be countered by centripetal forces in production, if different labour types are imperfectly substitutable. In fact, when labour types are imperfect substitutes, the relative productivity of individual types is not inferrable from wage and price information alone. Such inference also requires information on relative factor usage in the traded sector. Using the labour-demand equations for the traded sector, it is possible to show that the relative demand for labour depends on relative wages and relative productivity levels:

$$
\hat{N}_{1 X}^{j}-\hat{N}_{2 X}^{j}=-\sigma_{12}\left(\hat{w}_{1}^{j}-\hat{w}_{2}^{j}\right)+\left(\sigma_{12}-1\right)\left(\hat{A}_{1}^{j}-\hat{A}_{2}^{j}\right),
$$


where $\sigma_{12}$ is the elasticity of substitution between type- 1 and type- 2 labour. ${ }^{9}$ Intuitively, this (along with fixed land supplies) produces downward-sloping demand for particular labour types. For instance, one can imagine that producers of tradable output in Montreal could find having a few native English speakers to be very productive for helping to export its products. However, because of provincial laws requiring the use of French in the workplace, these workers would be less productive than comparable native French speakers if they were employed in equal proportion. Similarly, allophones may have some idiosyncratic skills that are imperfect substitutes for those possessed by other language groups, much as Ottaviano and Peri (2012) found for immigrants relative to natives in the United States.

As derived in the online technical appendix A.1.2, equation (11) implies that the productivity of type 2 workers is (with a symmetric expression for type 1) is

$$
\hat{A}_{2}^{j}=\frac{\theta_{N 1}^{j}}{\theta_{N 1}^{j}+\theta_{N 2}^{j}} \frac{\hat{N}_{2 X}^{j}-\hat{N}_{1 X}^{j}+\sigma_{12}\left(\hat{w}_{2}^{j}-\hat{w}_{1}^{j}\right)}{\sigma_{12}-1}+\hat{A}^{j} .
$$

This formula implies that the greater the elasticity of substitution between the two labour types, the more important wage differences are relative to employment differences in reflecting productivity differences. When labour types are strong substitutes, wages must offset the productivity differences of different types: as $\sigma_{12} \rightarrow \infty, \hat{A}_{2}^{j}=\left(\hat{w}_{2}^{j}-\hat{w}_{1}^{j}\right) \theta_{N 1}^{j} /\left(\theta_{N 1}^{j}+\theta_{N 2}^{j}\right)+\hat{A}^{j}$, which in the case where $N_{1}$ and $N_{2}$ are the only two factors is just $\hat{A}_{2}=\hat{w}_{2}$. But when substitution possibilities are more limited, firms are less able to bid up the relative wage of more productive labour, and relative factor usage becomes more informative.

\section{Empirical implementation}

To apply our model to Canada, we estimate city-specific wage and price differentials using Census micro-data for the reference year 2005 and calibrate the cost, income, expenditure, and tax parameters from other sources. ${ }^{10}$

\subsection{Data and the estimation of wage and housing-cost differentials}

We estimate wage and housing-cost differentials using the 2006 20\% Canadian Census Microdata Masterfile. Most of the differentials apply to a Census Metropolitan Area (CMA), which consist of municipalities located around an urban core with a population of at least 100,000. The remaining differentials are

9 This equation is often seen in the analysis of skill-biased technical change (e.g., Violante 2008).

10 The reference year for the earnings is the 2005 calendar year. For housing costs, it is the monthly average over the past 12 months with the reference day of interview being 16 May 2006. For renters, it is the current monthly rent paid. 
for non-CMA areas grouped by province. In total, there are 33 CMAs and 13 non-CMA areas.

\subsubsection{Wage differentials and union adjustments}

The inter-urban wage differentials come from a sample of full-time workers, ages 25 to 55, and control for observable skill differences across workers. Thus, for each language group, determined by the mother tongue of the worker, we regress log wages on CMA-indicators $\left(\nu_{w}^{j}\right)$ and on extensive controls $\left(X_{w}^{i}\right)$ in the equation $\ln w^{i j}=X_{w}^{i} \beta_{w}+v_{w}^{j}+\varepsilon_{w}^{i j}$. ${ }^{11}$ The estimated values of $v_{w}^{j}$, normalized to have a population-weighted average of zero, are our estimates of the log-wage differentials, $\hat{w}_{g}^{j}$. We interpret them as the causal effect of city characteristics on a worker's wage. Identifying these differentials requires that workers do not sort across cities according to their unobserved skills. ${ }^{12}$ The overall differential for each city, $\hat{w}^{j}$, is equal to the average of the $\hat{w}_{g}^{j}$ for each language group, weighted by the number of workers in each city. ${ }^{13}$

When controlling for location and additional controls, allophones earn wages $16 \%$ lower than anglophones while francophones earn $2 \%$ less. ${ }^{14}$ These differences within CMAs could be due to a variety of reasons, such as school quality or linguistic discrimination (Albouy 2008b).

As we document in appendix table A3, union coverage rates in Canada are high and differ substantially across CMAs, with coverage rates varying from $23 \%$ in Calgary to almost 50\% in Quebec, Sherbrooke, and Thunder Bay. To the extent that wages reflect marginal productivity and unions raise them beyond this competitive rate, it is appropriate to adjust them in order to estimate productivity levels. It is theoretically ambiguous whether union wage premia should be discounted when estimating QOL. If union jobs are readily accessible to new migrants, and these higher premia are reflected in higher rents and other costs of

11 We include a quartic in potential work experience, highest level education (12 indicators), field of study (17 indicators), occupation (24 indicators), industry (15 indicators), immigrant status interacted with the visible minority status (except for Aboriginal status), years since immigration, citizenship status, and bilingualism interacted with mother tongue. All these variables are fully interacted with gender. The online technical appendix B provides greater detail on the covariates and regressions. The estimates of the coefficients of the controls are also available in the online technical appendix.

12 This assumption may not hold completely. Glaeser and Maré (2001) argue that up to one-third of the urban-rural wage gap could be due to selection, suggesting that at least two-thirds of wage differentials are valid, although this issue deserves greater investigation. At the same time, it is possible that the estimates could be too small, as some control variables, such as occupation or industry, could depend on where the worker locates.

13 Note that in practice, some workers live and work in different CMAs. We determine the CMA of a worker by their place of work, so that our productivity estimates are clearly characteristic of the city. The QOL estimates should on the whole be more accurate, since they will represent the wages and costs faced by workers with relatively modest commutes. Regardless, the results are almost identical if we assign wage differentials by place of residence, rather than place of work.

14 Although these differentials control for the official languages the worker speaks, the Census does not indicate how proficient respondents are in their languages. It seems likely that self-reported bilingual anglophones speak English better than self-reported bilingual francophones do, and vice versa. 
living, then it would be inappropriate to discount the premia. If instead, union wage premia are not capitalized into higher land rents and local costs of living, then it is sensible to discount them. Otherwise, real incomes in highly unionized areas may be high relative to the local QOL, and QOL estimates in highly unionized areas will be biased downwards.

Unfortunately, the Census data do not contain information on union coverage. We were able to calculate CMA-level unionization rates from the Labour Force Survey, although these rates are not available by mother tongue. We eliminate inferred union-wage premia by multiplying the union coverage rates by a premium of $7.7 \mathrm{log}$ points, taken from Fang and Verma (2002), and subtracting them from the original estimates of $\hat{w}^{j}$, renormalizing them to have a population-weighted average value of zero.

The importance of the public sector varies greatly by cities. For example, a little less than $40 \%$ of workers are employed in the public sector in Ottawa compared with less than $15 \%$ in Toronto. Like unionization, this potentially has an impact on wages. To control for this, we account for the percentage of the workforce in each CMA that works in a public sector job. ${ }^{15}$

\subsubsection{Housing-cost differentials}

Following previous studies (e.g., Gabriel and Rosenthal 2004), we use both housing values and gross rents, including utilities, to calculate housing-cost differentials. For owned units, we multiply housing values times a discount rate of 7.85\% (Peiser and Smith 1985), and add utility costs, to impute rents comparable to gross rents. We regress the logarithm of these rents on flexible controls $\left(X_{w}^{i}\right)$ in the equation $\ln p^{i j}=X_{p}^{i} \beta_{p}+v_{p}^{j}+\varepsilon_{p}^{i j} .{ }^{16}$ The coefficients $v_{p}^{j}$, normalized to have a population-weighted average of zero, are our estimates of the housing-cost differentials, $\hat{p}^{j}$. Proper identification of housing-cost differences requires that average unobserved housing quality, and the extent of foreign investment, do not vary systematically across cities. ${ }^{17}$

15 We also imposed the restriction that $\beta_{w}$ is constant across cities. In analyses that we do not report, we did find evidence that there are some differences in the returns to characteristics across cities. For instance, university-educated workers receive less of a premium for working in Vancouver than high-school-educated workers. This suggests that the former enjoy a higher quality of life in Vancouver. While interesting, most of these return differences are relatively minor and, for the sake of simplicity, are left for future work.

16 The controls, which are interacted with renter-status, include number of rooms ( 9 indicators), number of bedrooms ( 5 indicators), number of rooms interacted with number of bedrooms, number of rooms per household member, type of building ( 7 indicators), age of building ( 9 indicators), and state of repair ( 2 indicators). For owner-occupied units, we include an indicator for condominium status and interact the controls with mortgage status. See the online technical appendix B for more detail. The estimates of the coefficients of the controls are available in the online technical appendix.

17 Unobserved housing quality differences should be minor, as Malpezzi et. al. (1998) determine that housing-cost indices derived from the U.S. Census in this way perform as well or better than most other indices. As well, in the admittedly limited data available, foreign investments in major Canadian housing markets appear to be small. For instance, Tal (2011) uses Landcor data, a comprehensive database on historical sales and current information on the $\mathrm{BC}$ 
Controlling for CMA and additional controls, we find that allophones have housing costs that are almost identical to those of anglophones, while francophones have housing costs that are around 13\% lower. The lower housing costs of francophones potentially reflect the fact that anglophones may live in more amenable areas within CMAs, such as Montreal, where historic anglophone neighbourhoods are generally considered very amenable. It could also be that anglophones face a more restricted housing market or enjoy better housing quality, which we cannot control for.

\subsection{Calibration}

The calibrated values for the parameters are similar to those for the United States found in Albouy (2009b), except that we amend them for Canada to account for a smaller share of income received by labour, and a smaller proportion of expenditures spent on locally produced goods.

$$
\begin{array}{llll}
s_{x}=0.67 & \theta_{L}=0.025 & \phi_{L}=0.25 & s_{R}=0.10 \\
s_{y}=0.33 & \theta_{N}=0.775 & \phi_{N}=0.55 & s_{w}=0.70 \\
& \theta_{K}=0.20 & \phi_{K}=0.20 & s_{I}=0.20
\end{array}
$$

Information on income and expenditure share differences by language group is lacking, and so we assume they are the same, which allows us to use equation (10) for our estimates.

The elasticity of substitution between different labour types is unknown. Ottaviano and Peri (2012) estimate the elasticity of substitution between immigrants and non-immigrant workers to be about 20 . It would seem that the elasticity of substitution between workers of different language groups is much higher than this elasticity, given that the workers were often born and raised in Canada and thus have even more similar skills. ${ }^{18}$ Thus, we use two potential values for $\sigma: \infty$ and 40 , where the latter illustrates the case of imperfect substitutability.

Although federal tax differences are included in the analysis, federal transfer and spending differences are not. These are discussed in section 6.1.

Calculated tax differentials depend on both federal and provincial tax rates. They include direct taxes on income as well as indirect taxes on consumption; since this is a static model without an intertemporal savings decision, the two are equivalent as taxes on consumption reduce the buying power of labour. We determine provincial differentials using wage differences within province only. Across provinces, the average marginal tax rate on labour income is $28 \%$. See the online technical appendix for more details. ${ }^{19}$

residential and commercial markets, to document that only $2.6 \%$ of all sales over the past five years can be accounted by owners whose tax notice is sent to addresses outside Canada.

18 We include immigrant controls to capture differences in immigrant/Canadian born earning outcomes. See the online technical appendix for more detail.

19 Many workers report receiving little income other than labour income. However, given the static nature of the model, a worker's choices should be modelled to account for a worker's permanent 


\section{Quality of life and productivity estimates}

\subsection{Main estimates}

Columns 2 and 3 of table 1 report the estimated wage and housing-cost differentials by CMA or non-CMA areas of provinces. Figure 1 graphs these and provides intuition for how we use them to infer overall QOL and productivity differentials, reported in columns 4 and 5. The figure displays the average mobility condition from (4a), with $\hat{Q}^{j}=0$, and the combined average zero-profit conditions from (6), with $\hat{A}^{j}=0$. The average mobility condition illustrates the housing costs households are willing to pay for a given wage; any premium above that housing cost level is inferred to be payment for consumption amenities, and thus the vertical distance above that condition indicates overall QOL, $\hat{Q}^{j}$. The combined zero-profit condition illustrates the rate at which land rents, inferred through housing costs, must fall, on average, as wages rise. Any premium over this is inferred to be payment for production amenities, and thus the vertical (or horizontal) distance from that condition indicates overall firm productivity in the traded sector, $\hat{A}^{j}$. Through a change in the coordinate system, the two conditions in figure 1 provide a set of axes for the new coordinate system in figure 2, which is in the space of productivity and QOL.

Interestingly, Canada's five largest CMAs - Toronto, Montreal, Vancouver, Ottawa-Hull, and Calgary - all have above-average productivity and QOL, as they lie above the average mobility-condition and to the right of the average zero-profit condition. The smaller cities of Halifax and Kelowna have aboveaverage QOL but much lower productivity, which is commensurate with their reputations as charming tourist destinations. Kitchener, Oshawa, and Windsor have less-than-average QOL, but are quite productive given their size, although this is likely to do with their proximity to Toronto and Detroit. Also in this category are the Territories, where high wages simultaneously reflect the high marginal productivity of the workers there, as well as the need for those workers to be compensated for the harsh climate and remote location. Finally, a large number of smaller cities, including Moncton, Regina, St. John's, Thunder Bay, and Trois-Rivières fall in the category of cities with below-average productivity and QOL, with the compensating benefit of being affordable. All of the nonCMA areas of provinces (except for those in BC) also fall in this category, suggesting that on average neither firms nor households find less urban areas to be exceptionally attractive.

The rankings of the cities in terms of overall QOL, productivity, and their combined value are given in table 2. Victoria has the highest QOL, followed by Vancouver, Kelowna, Abbotsford, and Toronto. Rounding out the top ten are Calgary, Montreal, Sherbrooke, Ottawa-Hull, and Barrie. Saint John, Windsor, and Thunder Bay take the bottom three spots. This list contrasts significantly 
TABLE 1

Prices, attributes, and values across Canadian cities

\begin{tabular}{|c|c|c|c|c|c|c|c|c|}
\hline \multirow[b]{2}{*}{$\begin{array}{l}\text { City/area } \\
\text { name }\end{array}$} & \multirow[b]{2}{*}{$\begin{array}{l}\text { Population } \\
\text { (1) }\end{array}$} & \multicolumn{2}{|c|}{ Observed prices } & \multicolumn{2}{|c|}{ Attribute } & \multicolumn{2}{|c|}{$\begin{array}{l}\text { Value } \\
\text { capitalization }\end{array}$} & \multirow[b]{2}{*}{$\begin{array}{l}\text { Total } \\
\text { value } \\
\text { (8) }\end{array}$} \\
\hline & & $\begin{array}{l}\text { Wages } \\
(2)\end{array}$ & $\begin{array}{l}\text { Housing } \\
\text { costs } \\
\text { (3) }\end{array}$ & $\begin{array}{l}\text { Quality } \\
\text { of life } \\
\text { (4) }\end{array}$ & $\begin{array}{l}\text { Product- } \\
\text { ivity } \\
\text { (5) }\end{array}$ & $\begin{array}{l}\text { Land } \\
\text { rent } \\
(6)\end{array}$ & $\begin{array}{l}\text { Tax } \\
\text { burden } \\
\text { (7) }\end{array}$ & \\
\hline \multicolumn{9}{|c|}{ Panel A: Census Metropolitan Areas } \\
\hline Vancouver & $2,047,650$ & 0.04 & 0.45 & 0.13 & 0.07 & 1.71 & 0.01 & 0.18 \\
\hline Victoria & 320,920 & -0.04 & 0.46 & 0.17 & 0.02 & 1.92 & -0.01 & 0.18 \\
\hline Toronto & $4,966,660$ & 0.10 & 0.29 & 0.05 & 0.10 & 0.93 & 0.02 & 0.11 \\
\hline Calgary & $1,053,840$ & 0.09 & 0.24 & 0.04 & 0.09 & 0.78 & 0.02 & 0.10 \\
\hline Kelowna & 159,490 & -0.07 & 0.24 & 0.11 & -0.03 & 1.09 & -0.02 & 0.09 \\
\hline Montreal & $3,534,850$ & 0.02 & 0.14 & 0.04 & 0.03 & 0.51 & 0.01 & 0.06 \\
\hline Ottawa-Hull & $1,106,380$ & 0.08 & 0.13 & 0.01 & 0.07 & 0.37 & 0.02 & 0.06 \\
\hline Abbotsford & 154,830 & -0.03 & 0.12 & 0.06 & -0.01 & 0.55 & -0.01 & 0.05 \\
\hline Guelph & 125,070 & 0.04 & 0.05 & 0.00 & 0.03 & 0.13 & 0.01 & 0.02 \\
\hline Hamilton & 676,780 & 0.03 & 0.05 & 0.00 & 0.03 & 0.14 & 0.01 & 0.02 \\
\hline Oshawa & 326,890 & 0.11 & 0.02 & -0.04 & 0.08 & -0.16 & 0.03 & 0.01 \\
\hline Edmonton & $1,013,400$ & 0.03 & -0.01 & -0.02 & 0.02 & -0.11 & 0.00 & -0.01 \\
\hline Kitchener & 441,420 & 0.05 & -0.02 & -0.03 & 0.03 & -0.18 & 0.01 & -0.01 \\
\hline Quebec & 701,420 & -0.02 & -0.02 & 0.00 & -0.02 & -0.03 & -0.01 & -0.01 \\
\hline Barrie & 174,420 & -0.04 & -0.03 & 0.01 & -0.03 & -0.02 & -0.01 & -0.02 \\
\hline Kingston & 147,230 & -0.05 & -0.05 & 0.00 & -0.04 & -0.08 & -0.01 & -0.02 \\
\hline Peterborough & 114,580 & -0.06 & -0.05 & 0.00 & -0.05 & -0.09 & -0.02 & -0.03 \\
\hline Sherbrooke & 182,330 & -0.09 & -0.06 & 0.02 & -0.07 & -0.04 & -0.02 & -0.03 \\
\hline $\begin{array}{l}\text { St. Catharines- } \\
\text { Niagara }\end{array}$ & 381,170 & -0.02 & -0.12 & -0.04 & -0.02 & -0.45 & -0.01 & -0.05 \\
\hline Brantford & 122,420 & -0.03 & -0.13 & -0.03 & -0.03 & -0.46 & -0.01 & -0.05 \\
\hline Halifax & 366,790 & -0.11 & -0.16 & 0.01 & -0.09 & -0.39 & -0.02 & -0.06 \\
\hline London & 447,310 & 0.01 & -0.15 & -0.06 & -0.01 & -0.64 & 0.00 & -0.06 \\
\hline Windsor & 316,170 & 0.10 & -0.21 & -0.11 & 0.05 & -1.06 & 0.03 & -0.08 \\
\hline Sudbury & 155,990 & 0.03 & -0.23 & -0.09 & 0.00 & -0.97 & 0.01 & -0.09 \\
\hline Trois-Rivières & 138,160 & -0.01 & -0.26 & -0.08 & -0.03 & -1.01 & -0.00 & -0.10 \\
\hline $\begin{array}{l}\text { Chicoutimi- } \\
\text { Jonquière }\end{array}$ & 149,440 & 0.01 & -0.28 & -0.10 & -0.02 & -1.16 & 0.01 & -0.11 \\
\hline Winnipeg & 677,500 & -0.08 & -0.29 & -0.05 & -0.09 & -0.99 & -0.01 & -0.11 \\
\hline Saskatoon & 228,080 & -0.10 & -0.30 & -0.05 & -0.10 & -0.98 & -0.02 & -0.12 \\
\hline Regina & 190,790 & -0.04 & -0.34 & -0.09 & -0.06 & -1.27 & -0.00 & -0.13 \\
\hline Moncton & 123,580 & -0.13 & -0.35 & -0.05 & -0.13 & -1.13 & -0.02 & -0.14 \\
\hline Thunder Bay & 120,720 & -0.01 & -0.39 & -0.13 & -0.04 & -1.54 & 0.00 & -0.15 \\
\hline St. John's & 178,170 & -0.12 & -0.44 & -0.09 & -0.13 & -1.50 & -0.02 & -0.17 \\
\hline $\begin{array}{l}\text { Saint John } \\
\text { Non-CMA Areas }\end{array}$ & 119,800 & -0.11 & -0.49 & -0.11 & -0.13 & -1.74 & -0.01 & -0.19 \\
\hline $\begin{array}{l}\text { British } \\
\quad \text { Columbia }\end{array}$ & $1,327,040$ & -0.05 & -0.05 & 0.01 & -0.04 & -0.09 & -0.01 & -0.02 \\
\hline $\begin{array}{l}\text { Northwest } \\
\text { Territories }\end{array}$ & 40,770 & 0.19 & -0.06 & -0.12 & 0.13 & -0.66 & 0.04 & -0.03 \\
\hline Yukon & 29,960 & 0.04 & -0.12 & -0.06 & 0.02 & -0.55 & 0.01 & -0.05 \\
\hline Alberta & $1,153,770$ & -0.03 & -0.16 & -0.04 & -0.04 & -0.58 & -0.01 & -0.07 \\
\hline Ontario & $2,530,520$ & -0.05 & -0.20 & -0.05 & -0.06 & -0.69 & -0.01 & -0.08 \\
\hline Quebec & $2,386,520$ & -0.08 & -0.30 & -0.06 & -0.09 & -1.01 & -0.02 & -0.12 \\
\hline $\begin{array}{l}\text { Prince Edward } \\
\text { Island }\end{array}$ & 133,830 & -0.24 & -0.48 & -0.04 & -0.22 & -1.37 & -0.05 & -0.19 \\
\hline
\end{tabular}


TABLE 1

(Continued)

\begin{tabular}{|c|c|c|c|c|c|c|c|c|}
\hline \multirow[b]{2}{*}{$\begin{array}{l}\text { City/area } \\
\text { name }\end{array}$} & \multirow[b]{2}{*}{$\begin{array}{l}\text { Population } \\
\text { (1) }\end{array}$} & \multicolumn{2}{|c|}{ Observed prices } & \multicolumn{2}{|c|}{ Attribute } & \multicolumn{2}{|c|}{$\begin{array}{l}\text { Value } \\
\text { capitalization }\end{array}$} & \multirow[b]{2}{*}{$\begin{array}{l}\text { Total } \\
\text { value } \\
\text { (8) }\end{array}$} \\
\hline & & $\begin{array}{l}\text { Wages } \\
(2)\end{array}$ & $\begin{array}{l}\text { Housing } \\
\text { costs } \\
\text { (3) }\end{array}$ & $\begin{array}{l}\text { Quality } \\
\text { of life } \\
\text { (4) }\end{array}$ & $\begin{array}{l}\text { Product- } \\
\text { ivity } \\
\text { (5) }\end{array}$ & $\begin{array}{l}\text { Land } \\
\text { rent } \\
(6)\end{array}$ & $\begin{array}{l}\text { Tax } \\
\text { burden } \\
\text { (7) }\end{array}$ & \\
\hline Nunavut & 29,270 & 0.25 & -0.55 & -0.31 & 0.13 & -2.75 & 0.05 & -0.22 \\
\hline $\begin{array}{l}\text { New } \\
\text { Brunswick }\end{array}$ & 473,080 & -0.18 & -0.59 & -0.11 & -0.19 & -1.95 & -0.04 & -0.23 \\
\hline Nova Scotia & 532,270 & -0.23 & -0.60 & -0.09 & -0.22 & -1.88 & -0.05 & -0.24 \\
\hline Manitoba & 445,220 & -0.19 & -0.63 & -0.12 & -0.20 & -2.09 & -0.04 & -0.25 \\
\hline Saskatchewan & 529,430 & -0.20 & -0.75 & -0.15 & -0.22 & -2.55 & -0.04 & -0.30 \\
\hline Newfoundland & 320,930 & -0.18 & -0.95 & -0.23 & -0.22 & -3.40 & -0.03 & -0.37 \\
\hline \multicolumn{9}{|c|}{ Standard deviations across areas } \\
\hline Canada & $30,896,860$ & 0.09 & 0.30 & 0.07 & 0.06 & 0.71 & 0.02 & 0.08 \\
\hline
\end{tabular}

NOTES: Wage and housing cost data are taken from the Census 2006 Masterfiles. Wage differentials are based on the average logarithm of hourly wages for full-time workers ages 25 to 55 , controlling for observable skills. Housing cost differentials are based on the average logarithm of rents and housing price, controlling for observable housing characteristics. Quality of life, productivity, land rent, tax burden, and total value differentials are based on formulas explained in section 2.2.1 in the text for the one-household-type case. Fuller details on the data are in the online technical appendix.

with that of Giannias (1998), who places Edmonton and Winnipeg in the top 4 of 13 cities, which here are ranked 17 and 24 out of 33 .

From the second column of table 2, we see that Toronto is the leader in productivity, which is not surprising, given that it is the largest city and home of the financial centre of Canada. Second is Calgary, only the fifth-largest CMA at that time, but with a strong oil and gas industry. Third is Oshawa, as it is 50 kilometres from Toronto, with a strong base in automobile manufacturing. Vancouver and Ottawa-Hull round out the top five. All of these cities pay a disproportionate share of federal taxes per capita, as seen in column 7 of table 1 , as a result of being so productive. Despite being the second-largest CMA in Canada, Montreal is only in tenth place, possibly because of its language barrier with the rest of Canada and the United States.

The land-rent and total-value differentials are reported in columns 6 and 8 of table 1, with their difference caused by the tax differentials in column 7 , and the ranking reported in column 3 of table 2 . Their calculation is made visually transparent in figures 1 and 2 through the average iso-rent and iso-value curves; cities above these lines have above-average rents and total values, respectively. From these we see that Victoria has the highest private value of land, although Vancouver has the highest social value, as its higher wage levels lead to greater positive tax externalities for other Canadians. 


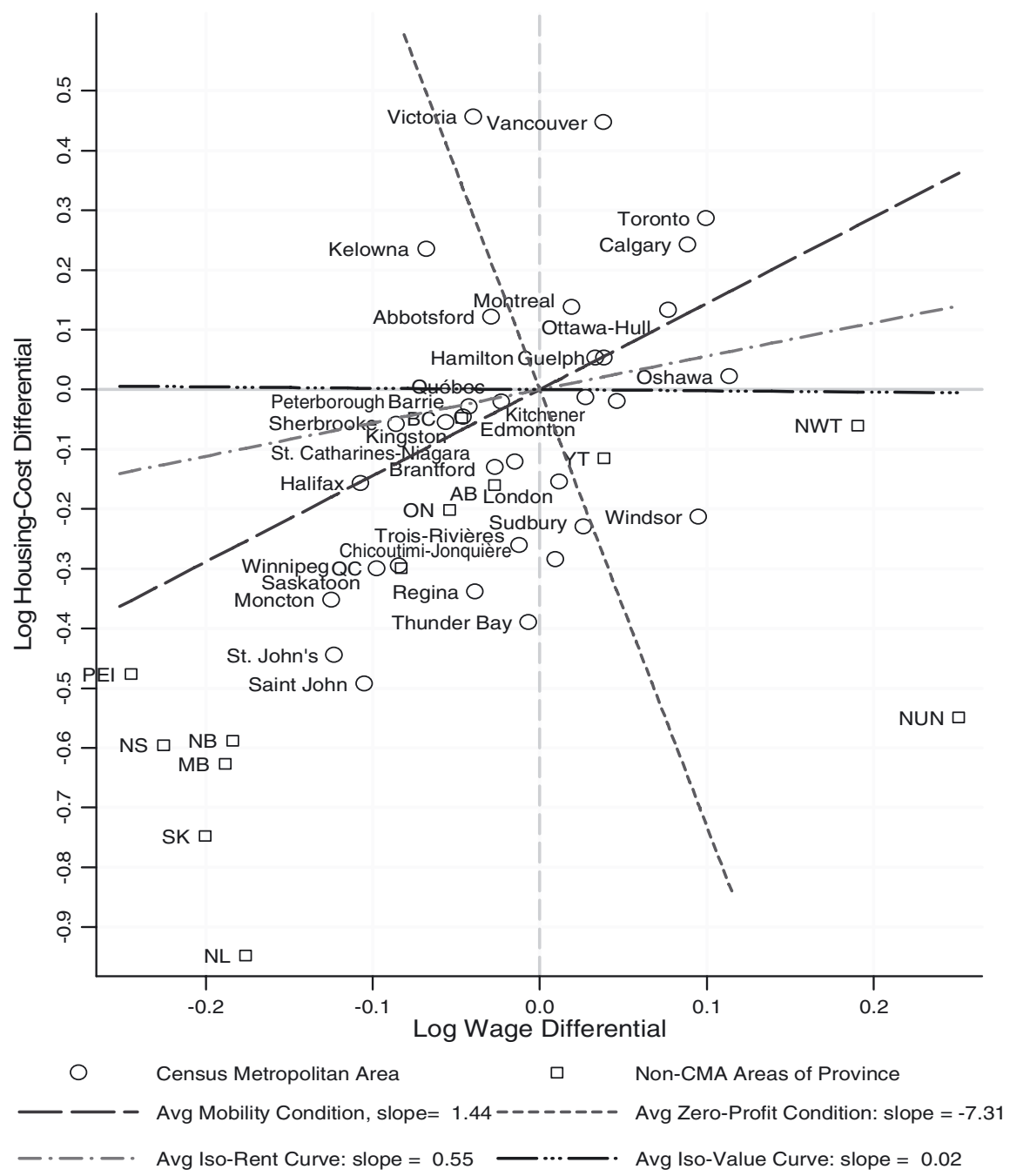

FIGURE 1 Housing costs versus wage levels across CMAs

\subsection{Estimates for separate language groups}

QOL measures broken down by mother tongue are presented in table 3 for CMAs with at least 100,000 inhabitants with that mother tongue, and where they constitute at least $10 \%$ of the population. Calculating QOL measures for cities where a smaller number of individuals have a certain mother tongue raises difficult econometric issues. ${ }^{20}$ On the whole, the QOL rankings for the different language

20 In places where a linguistic group is a small minority, the calculated wage differentials tend to be relatively low and the housing-cost differentials between language groups relatively high. See 


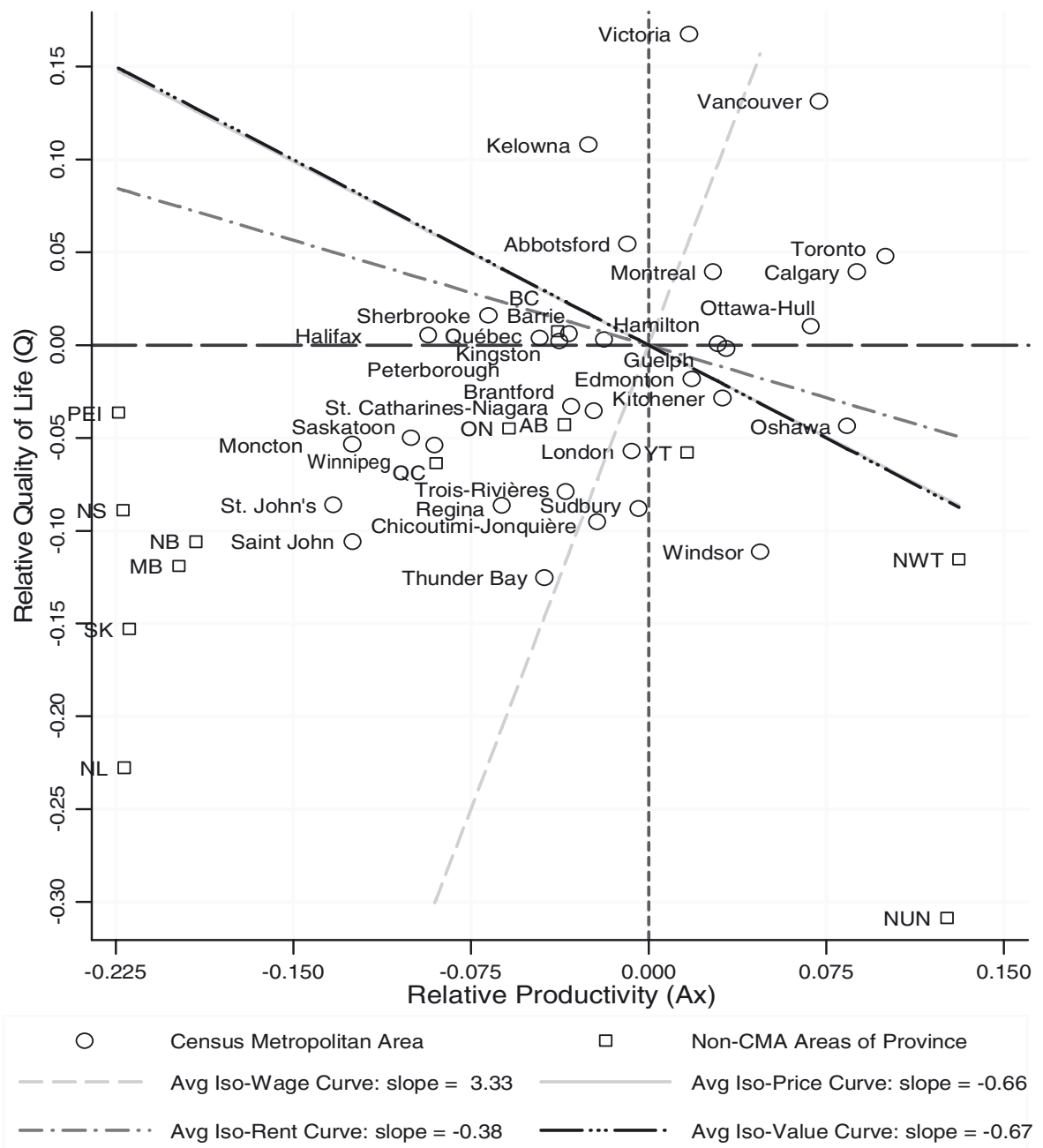

FIGURE 2 Estimated productivity and quality of life

groups are almost identical to those pooling everyone together. For instance, all of the groups prefer Montreal over Ottawa-Hull. The only discrepancy is minor: unlike anglophones, allophones appear to view Hamilton slightly more favourably than Ottawa-Hull, perhaps because they make up a larger fraction of the population. Francophones do not seem averse to living in linguistically diverse CMAs, as Montreal and Ottawa-Hull are their top two cities, while the worst two

Warman (2007) for Canadian analysis and evidence of enclaves. It is likely that these individuals have idiosyncratic attachments, such as spouses, that cause them to sacrifice real income in order to live in these places. 
TABLE 2

Census metropolitan area rankings

\begin{tabular}{|c|c|c|c|}
\hline & Quality of life ranking & Productivity ranking & Total value ranking \\
\hline 1 & Victoria & Toronto & Vancouver \\
\hline 2 & Vancouver & Calgary & Victoria \\
\hline 3 & Kelowna & Oshawa & Toronto \\
\hline 4 & Abbotsford & Vancouver & Calgary \\
\hline 5 & Toronto & Ottawa-Hull & Kelowna \\
\hline 6 & Calgary & Windsor & Montreal \\
\hline 7 & Montreal & Guelph & Ottawa-Hull \\
\hline 8 & Sherbrooke & Kitchener & Abbotsford \\
\hline 9 & Ottawa-Hull & Hamilton & Guelph \\
\hline 10 & Barrie & Montreal & Hamilton \\
\hline 11 & Halifax & Edmonton & Oshawa \\
\hline 12 & Peterborough & Victoria & Edmonton \\
\hline 13 & Quebec & Sudbury & Kitchener \\
\hline 14 & Kingston & London & Quebec \\
\hline 15 & Hamilton & Abbotsford & Barrie \\
\hline 16 & Guelph & Quebec & Kingston \\
\hline 17 & Edmonton & Chicoutimi-Jonquière & Peterborough \\
\hline 18 & Kitchener & St. Catharines-Niagara & Sherbrooke \\
\hline 19 & Brantford & Kelowna & St. Catharines-Niagara \\
\hline 20 & St. Catharines-Niagara & Brantford & Brantford \\
\hline 21 & Oshawa & Barrie & Halifax \\
\hline 22 & Saskatoon & Trois-Rivières & London \\
\hline 23 & Moncton & Kingston & Windsor \\
\hline 24 & Winnipeg & Thunder Bay & Sudbury \\
\hline 25 & London & Peterborough & Trois-Rivières \\
\hline 26 & Trois-Rivières & Regina & Chicoutimi-Jonquière \\
\hline 27 & St. John's & Sherbrooke & Winnipeg \\
\hline 28 & Regina & Winnipeg & Saskatoon \\
\hline 29 & Sudbury & Halifax & Regina \\
\hline 30 & Chicoutimi-Jonquière & Saskatoon & Moncton \\
\hline 31 & Saint John & Saint John & Thunder Bay \\
\hline 32 & Windsor & Moncton & St. John's \\
\hline 33 & Thunder Bay & St. John's & Saint John \\
\hline
\end{tabular}

NOTES: Rankings are based on data in table 1.

are Trois-Rivières and Chicoutimi-Jonquière. Allophones prefer Canada's three largest cities, Vancouver, Toronto, and Montreal, over all other ones, supporting the notion that allophones will prefer to live in areas with the greatest number of like-tongued speakers.

The individual productivity of different language groups is given in table 4 for just a few cities where the supply of each group is large enough to produce credible estimates. Panel A considers the productivity differences between francophones and anglophones in Montreal and Ottawa-Hull. In Montreal, average productivity is $3 \%$ above the national average, and francophones are better paid and much more heavily employed than anglophones. If both types of workers are perfect substitutes, then francophones from Montreal are 4\% more productive than the average francophone, while anglophones are $4 \%$ less 
TABLE 3

Wage, housing-cost, and quality of life differentials by mother tongue

\begin{tabular}{|c|c|c|c|c|c|c|}
\hline Rank & Name & $\begin{array}{l}\text { Population } \\
\text { of group }\end{array}$ & $\begin{array}{l}\text { Fraction } \\
\text { of total }\end{array}$ & Wages & $\begin{array}{l}\text { Housing } \\
\text { cost }\end{array}$ & $\begin{array}{l}\text { Quality } \\
\text { of life }\end{array}$ \\
\hline \multicolumn{7}{|c|}{ Panel A: Anglophones } \\
\hline 1 & Victoria & 275,930 & 0.86 & -0.04 & 0.48 & 0.18 \\
\hline 2 & Vancouver & $1,215,480$ & 0.59 & 0.06 & 0.52 & 0.14 \\
\hline 3 & Kelowna & 136,450 & 0.86 & -0.07 & 0.25 & 0.11 \\
\hline 4 & Abbotsford & 111,720 & 0.72 & -0.04 & 0.17 & 0.07 \\
\hline 5 & Toronto & $2,823,580$ & 0.57 & 0.14 & 0.38 & 0.06 \\
\hline 6 & Montreal & 448,710 & 0.13 & -0.02 & 0.12 & 0.05 \\
\hline 7 & Calgary & 805,620 & 0.76 & 0.10 & 0.28 & 0.05 \\
\hline 8 & Ottawa-Hull & 561,760 & 0.51 & 0.07 & 0.14 & 0.01 \\
\hline 9 & Guelph & 101,260 & 0.81 & 0.02 & 0.08 & 0.01 \\
\hline 10 & Hamilton & 521,760 & 0.77 & 0.04 & 0.09 & 0.01 \\
\hline 11 & Barrie & 155,420 & 0.89 & -0.04 & -0.02 & 0.01 \\
\hline 12 & Kingston & 130,340 & 0.89 & -0.05 & -0.04 & 0.01 \\
\hline 13 & Peterborough & 106,690 & 0.93 & -0.06 & -0.05 & 0.00 \\
\hline 14 & Halifax & 338,550 & 0.92 & -0.11 & -0.17 & 0.00 \\
\hline 15 & Edmonton & 795,610 & 0.79 & 0.03 & 0.02 & -0.01 \\
\hline 16 & Kitchener & 337,780 & 0.77 & 0.05 & 0.02 & -0.02 \\
\hline 17 & Brantford & 108,240 & 0.88 & -0.03 & -0.12 & -0.03 \\
\hline 18 & St. Catharines-Niagara & 309,680 & 0.81 & -0.02 & -0.11 & -0.03 \\
\hline 19 & Oshawa & 285,270 & 0.87 & 0.12 & 0.03 & -0.04 \\
\hline 20 & Winnipeg & 515,180 & 0.76 & -0.08 & -0.27 & -0.05 \\
\hline 21 & Saskatoon & 198,190 & 0.87 & -0.10 & -0.29 & -0.05 \\
\hline 22 & London & 366,120 & 0.82 & 0.01 & -0.13 & -0.05 \\
\hline 23 & Regina & 170,940 & 0.90 & -0.04 & -0.33 & -0.08 \\
\hline 24 & St. John's & 174,350 & 0.98 & -0.12 & -0.44 & -0.09 \\
\hline 25 & Sudbury & 101,230 & 0.65 & 0.00 & -0.31 & -0.10 \\
\hline 26 & Windsor & 234,100 & 0.74 & 0.09 & -0.19 & -0.10 \\
\hline 27 & Saint John & 111,370 & 0.93 & -0.12 & -0.51 & -0.11 \\
\hline 28 & Thunder Bay & 101,930 & 0.84 & -0.01 & -0.38 & -0.12 \\
\hline \multicolumn{7}{|c|}{ Panel B: Francophones } \\
\hline 1 & Montreal & $2,359,840$ & 0.67 & 0.06 & 0.21 & 0.05 \\
\hline 2 & Ottawa-Hull & 366,230 & 0.33 & 0.10 & 0.21 & 0.03 \\
\hline 3 & Sherbrooke & 165,740 & 0.91 & -0.08 & -0.03 & 0.02 \\
\hline 4 & Quebec & 672,750 & 0.96 & -0.02 & -0.01 & 0.01 \\
\hline 5 & Trois-Rivières & 134,530 & 0.97 & -0.01 & -0.25 & -0.08 \\
\hline 6 & Chicoutimi-Jonquière & 146,680 & 0.98 & 0.01 & -0.28 & -0.09 \\
\hline \multicolumn{7}{|c|}{ Panel C: Allophones } \\
\hline 1 & Vancouver & 806,880 & 0.39 & 0.00 & 0.32 & 0.11 \\
\hline 2 & Toronto & $2,080,620$ & 0.42 & 0.04 & 0.15 & 0.03 \\
\hline 3 & Montreal & 726,300 & 0.21 & -0.10 & -0.13 & 0.01 \\
\hline 4 & Calgary & 231,480 & 0.22 & 0.06 & 0.06 & -0.01 \\
\hline 5 & Hamilton & 144,830 & 0.21 & 0.01 & -0.12 & -0.05 \\
\hline 6 & Ottawa-Hull & 178,380 & 0.16 & 0.05 & -0.09 & -0.05 \\
\hline 7 & Edmonton & 195,240 & 0.19 & 0.01 & -0.18 & -0.07 \\
\hline 8 & Winnipeg & 132,890 & 0.20 & -0.12 & -0.49 & -0.10 \\
\hline
\end{tabular}

NOTES: Wage and housing-cost differentials are calculated by language group according to the component orthogonal to observable characteristics but related to the CMA indicators interacted with language-group indicators. 
TABLE 4

Relative productivity of specific mother tongues in selected cities

\begin{tabular}{|c|c|c|c|c|c|c|c|}
\hline \multicolumn{4}{|c|}{ Panel A: Francophones relative to anglophones } & \multicolumn{4}{|c|}{$\begin{array}{l}\text { Mother-tongue-specific productivity } \\
\sigma=\infty \quad \sigma=40\end{array}$} \\
\hline \multirow[b]{2}{*}{ CMA } & \multicolumn{2}{|c|}{ Relative log ratio } & \multirow{2}{*}{$\begin{array}{l}\text { Total } \\
\text { prod }\end{array}$} & \multirow{2}{*}{$\begin{array}{l}\text { Franco- } \\
\text { phone }\end{array}$} & \multirow{2}{*}{$\begin{array}{l}\text { Anglo- } \\
\text { phone }\end{array}$} & \multirow{2}{*}{$\begin{array}{l}\text { Franco- } \\
\text { phone }\end{array}$} & \multirow{2}{*}{$\begin{array}{l}\text { Anglo- } \\
\text { phone }\end{array}$} \\
\hline & Wages & Employment & & & & & \\
\hline & 0 & & & 0.0 & -0. & 0.047 & -0 \\
\hline Ottawa-Hull & 0.029 & 0.560 & 0.069 & 0.085 & 0.057 & 0.094 & 0.051 \\
\hline
\end{tabular}

Panel B: Allophones relative to anglophones

\begin{tabular}{|c|c|c|c|c|c|c|c|}
\hline \multirow[b]{3}{*}{ CMA } & \multirow{2}{*}{\multicolumn{2}{|c|}{ Relative log ratio }} & \multirow{3}{*}{$\begin{array}{l}\text { Total } \\
\text { prod }\end{array}$} & \multicolumn{2}{|l|}{$\sigma=\infty$} & \multicolumn{2}{|l|}{$\sigma=40$} \\
\hline & & & & \multirow{2}{*}{$\begin{array}{l}\text { Allo- } \\
\text { phone }\end{array}$} & \multirow{2}{*}{$\begin{array}{l}\text { Anglo- } \\
\text { phone }\end{array}$} & \multirow{2}{*}{$\begin{array}{l}\text { Allo- } \\
\text { phone }\end{array}$} & \multirow{2}{*}{$\begin{array}{l}\text { Anglo- } \\
\text { phone }\end{array}$} \\
\hline & Wages & Employment & & & & & \\
\hline Toron & -0.096 & 0.878 & 0.100 & 0.046 & 0.142 & 0.058 & 0.133 \\
\hline Vancouver & -0.062 & 0.643 & 0.072 & 0.034 & 0.095 & 0.043 & 0.090 \\
\hline
\end{tabular}

NOTES: Wage and employment ratios are expressed in logarithms relative to the national log ratio (i.e., subtracting the national log ratio). Productivity levels are relative to others in the same language group and are calculated based on equation (12) in the text.

productive, making them about as productive as anglophones in Kingston. If anglophones provide special skills that cannot be easily substituted for by francophone labour, then the productivity differences are even larger: with an elasticity of substitution of 40 , an anglophone worker in Montreal is only $10 \%$ less productive, comparable anglophones in Saskatoon, and wages are as high as they are only because francophones cannot easily replace them. The results for Ottawa-Hull are much less extreme, since their national wage and employment differentials are roughly the same.

Panel B considers the productivity differences between anglophones and allophones in Toronto and Vancouver. In both CMAs, allophones earn less of a premium than anglophones do, but are hired in a greater proportion, relative to the national average. Thus, the less substitutable allophone labour is for anglophone labour, the closer their relative productivity differentials. It appears that anglophones in Vancouver have productivity levels just behind Calgary and ahead of Oshawa.

\section{Relationship with popular rankings and amenities}

The press abounds with popular rankings of Canadian cities according to many characteristics aimed at capturing 'livability.' Here, we compare our rankings based on revealed preference with the livability ratings from Places Rated Almanac and Cities Ranked and Rated. The popular measures are not grounded in theory and are largely ad hoc; they reflect popular perceptions of what characteristics make cities 'nice' to live in. Unlike the rankings based on willingnessto-pay, the popular rankings also incorporate low cost-of-living and good jobmarket opportunities as 'amenities.' In the hedonic framework above, if these 
TABLE 5

Correlation of economic quality of life and popular rankings

\begin{tabular}{lll}
\hline & $\begin{array}{l}\text { Places Rated } \\
\text { Almanac } \\
(1)\end{array}$ & $\begin{array}{l}\text { Cities Ranked } \\
\text { \& Rated } \\
(2)\end{array}$ \\
\hline Hedonic QOL rank & 0.71 & 0.72 \\
Places Rated Almanac & & 0.84 \\
\hline
\end{tabular}

factors are properly weighted, they should make all of the cities offer the same utility, making them equally 'livable.' In practice, the popular rankings put less weight on cost-of-living and job-market opportunities than the framework suggests. ${ }^{21}$

Table 5 reports the correlation coefficients between the popular rankings and the overall QOL ranking shown in table 1. All the correlations are strongly positive, the correlation between the two popular rankings being somewhat stronger than that between either popular ranking and the economic one. These correlations are strong despite the fact that the popular rankings include offsetting cost-of-living and job-market opportunities. The general consistency of the rankings seems to be mutually reinforcing to both the economic and the popular measures of QOL.

Table 6 estimates the relationship between the economic QOL estimates and ratings given to cities by Places Rated Almanac along various dimensions. The overall livability index in the Almanac puts equal weight on all of the estimates. Hedonic estimates based on the economic measures of QOL indicate that only the indices for climate and arts and culture have a significant relationship with households' willingness-to-pay. This holds true whether or not CMAs are weighted by population. With only 24 overlapping CMAs in the sample, this test does have low power; indeed, factors related to health, crime, and education may be very important in households' location decisions. But it appears unlikely that Places Rated was correct to assign each sub-index the same coefficient; our economic QOL index suggests that the restriction that all of the subindices should have equal coefficients is strongly rejected by the data. Understandably, Canadians care tremendously about climate. They also appear to care considerably about arts and culture or other amenities that are correlated with that index, not accounted for by the other indices.

\section{Additional considerations}

The model presented above has the advantage of requiring limited data, and of being intuitive to graph. Yet additional considerations should be examined, in particular with regard to non-housing costs, federal fiscal transfers, and housing

21 For instance, in Places Rated, cost-of-living and employment opportunities, are counted as two among nine amenities, all of which receive equal weight. 
TABLE 6

Quality of life, productivity, and disaggregated amenities from Places Rated Almanac

\begin{tabular}{lcc}
\hline & $\begin{array}{c}\text { Quality of life } \\
\text { (unweighted) } \\
(1)\end{array}$ & $\begin{array}{c}\text { Quality of life } \\
\text { (pop weight) } \\
(2)\end{array}$ \\
\hline Arts \& Culture & 0.08 & 0.13 \\
& $(0.04)$ & $(0.05)$ \\
Climate & 0.20 & 0.16 \\
& $(0.06)$ & $(0.05)$ \\
Crime & 0.05 & 0.04 \\
& $(0.06)$ & $(0.05)$ \\
Education & 0.07 & 0.06 \\
& $(0.07)$ & $(0.08)$ \\
Recreation & -0.01 & -0.03 \\
& $(0.07)$ & $(0.05)$ \\
Health & 0.07 & 0.08 \\
& $(0.07)$ & $(0.06)$ \\
Transportation & -0.04 & 0.00 \\
& $(0.07)$ & $(0.07)$ \\
Constant & -0.21 & 0.24 \\
& $(0.06)$ & $0.06)$ \\
Adjusted R-squared & 0.59 & 24 \\
Number of observations & 24 & 0.01 \\
$p$-value of test that all coefficients are equal & 0.01 & \\
\hline
\end{tabular}

NOTES: Robust standard errors are in parentheses. Regressions in the second column are weighted by the sum of individuals in each CMA.

rents. We believe it is unclear whether these considerations should be incorporated into the QOL and productivity estimates. Furthermore, much of the data are available only at the provincial level. Adjusted figures are presented separately in the appendix. The results are also summarized at the provincial and regional levels in table $7 .{ }^{22}$

\subsection{Intergovernmental transfers}

We adjust for intergovernmental transfers and provincial source-based tax revenues in column 9. If these payments benefit households, they should be subtracted from QOL; if they benefit firms, they should be subtracted from productivity; in either case they should be subtracted from the total value. On the other hand, if these payments benefit neither households nor firms then they should be ignored altogether. Assuming that the payments do affect the total value in some form, they raise the value of Ontario and Quebec, while the Atlantic and the Prairie provinces are seen as less valuable. As analyzed in greater detail in Albouy (2012), this is mainly driven by equalization payments, except for Alberta and Saskatchewan, which receive large fiscal benefits by retaining provincial revenues from taxes on natural resources, rather than sharing them federally.

22 CMA-level adjustments for QOL and total value, assuming that federal transfers are passed on directly to households, are presented in appendix tables A1 and A2. 


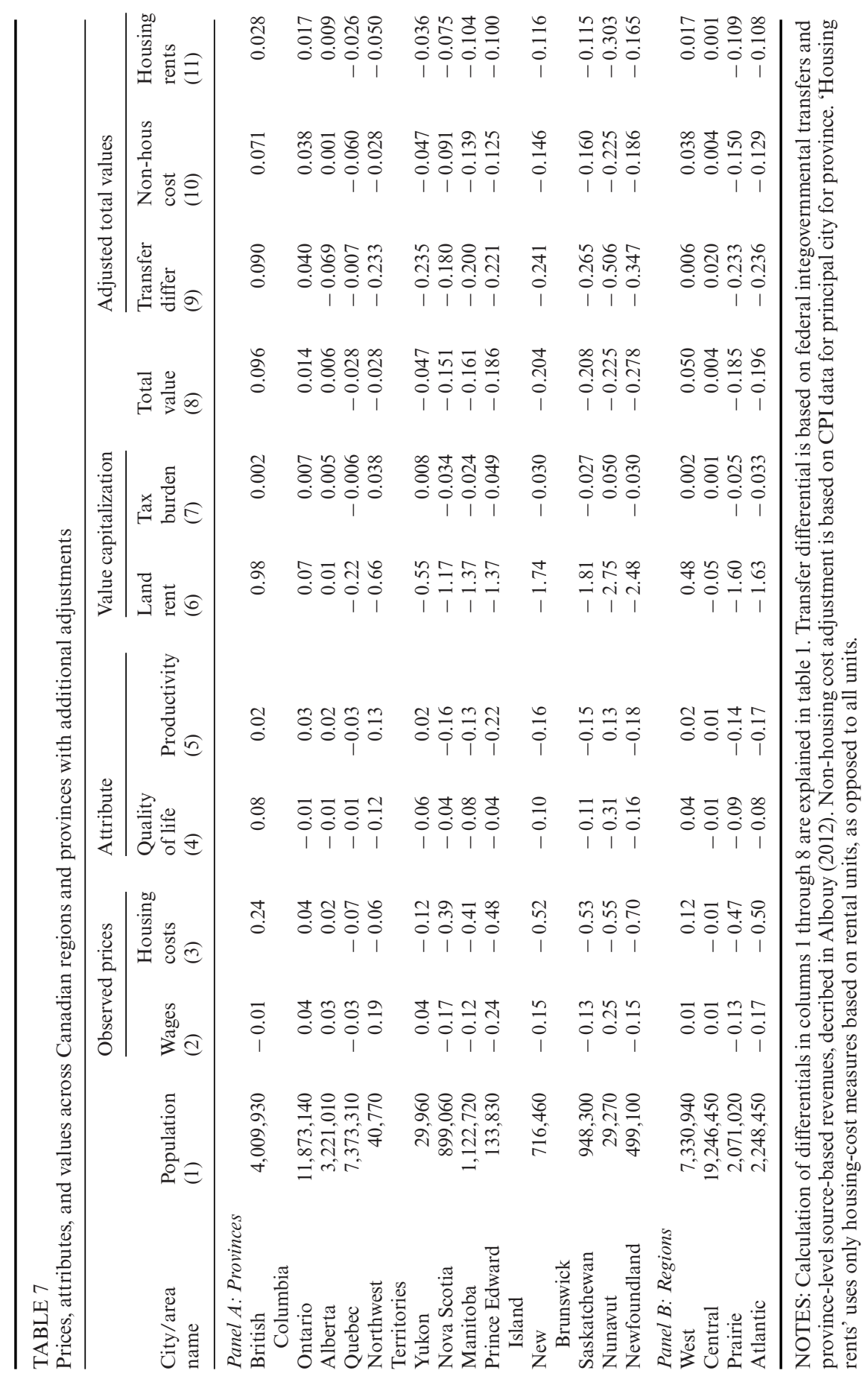




\subsection{Non-housing costs}

According to intercity estimates of the Consumer Price Index (CPI), non-housing cost differences are not always proportional to housing-cost differences, as we assumed above. If non-housing costs in an area are high relative to housing costs, then the cost-of-living measure approximated by housing costs is biased downwards in that area. This causes QOL measures in areas with high nonhousing costs to be biased downwards. This may be the case in more remote areas of Canada, such as the Territories, where housing is relatively cheap, but other goods are expensive because of transportation costs. ${ }^{23}$

Unfortunately, only one city per province has detailed CPI information. As a result, we need to assume that provincial cost differences are reflected in the representative CMAs, typically each province's largest. These adjustments, in column 10, suggest that QOL and total values may be underestimated in the Atlantic provinces, especially Newfoundland, and overestimated in Quebec.

\subsection{Housing rents}

Our main analysis measures housing costs by combining actual rents with imputed rents for owner-occupied units. There may be reason to doubt the accuracy of these imputed rent measures, especially during our time period, as housing prices in some markets rose considerably up until 2006. We construct alternate measures using only rented units, which we plot in appendix figure A1 against our main estimates of housing costs. Rents are strongly correlated with our measure of housing costs, but vary less. As seen in column 11 of table 7, using rent-only measures has a fairly minor effect on the overall rankings.

We believe rent-only measures are less accurate than our main measures. Rental units tend to be more centrally located than owned units and hence less representative of the overall CMA, especially as the majority of Canadians own their homes. In addition, home-ownership rates are generally higher in larger CMAs. Our main housing-cost measures are less prone to potential bias resulting from sample-selection issues.

\section{Conclusion}

This paper presents the first hedonic estimates of QOL and local productivity differences for Canada, accounting for heterogeneity in mother tongues and unionization rates. These measures seem sensible and intuitive, with the QOL measures exhibiting a strong positive correlation with favourable climate,

23 Unfortunately, the intercity CPI estimates do not reliably measure housing costs, as they rely on a subsample of new housing generally built on the urban fringe: 'The sample of builders for each metropolitan area is determined through the use of local market intelligence and verified against relevant building permit data. Where possible, prices are collected from builders who develop entire subdivisions, usually on large tracts of land.' The Census sample is more reliable as it samples all housing. For example in Vancouver, the CPI estimates that housing is only $10 \%$ over the national average, as opposed to $43 \%$ according to the Census data. 
cultural amenities, and popular rankings. We find Victoria has the greatest quality of life, Toronto has the highest productivity, and Vancouver has the most valuable combination of the two. Among cities that they jointly inhabit, Canada's different language groups appear largely to agree on which cities are more attractive, even when they live in different neighbourhoods. Local productivity is largely determined by size, but is also affected by other factors such as predominant language, access to natural resources, and proximity to other large cities.

Overall, our estimates measure how valuable different Canadian cities are, not only in producing the goods that households value, but also in delivering the amenities that households want. Most Canadians seem to prefer the amenities of larger metropolitan areas and are willing to consume fewer goods in order to live in them. In these larger metros, Canadians produce more valuable goods, to the benefit of local land owners and the federal government. Despite Canada's enormous wealth in natural resources, the greatest resource Canadians seem to value in production and consumption is each other.

\section{Appendix}

TABLE A1

Alternative quality-of-life measures using adjustments

\begin{tabular}{|c|c|c|c|c|c|c|c|c|}
\hline & \multicolumn{2}{|c|}{ Base QOL } & \multicolumn{2}{|c|}{$\begin{array}{l}\text { Transfer-adjusted } \\
\text { QOL }\end{array}$} & \multicolumn{2}{|c|}{$\begin{array}{l}\text { Non-housing } \\
\text { cost-adjusted } \\
\text { QOL }\end{array}$} & \multicolumn{2}{|c|}{$\begin{array}{l}\text { Rent-adjusted } \\
\text { QOL }\end{array}$} \\
\hline & $\begin{array}{l}\text { Value } \\
\text { (1) }\end{array}$ & $\begin{array}{l}\text { Rank } \\
\text { (2) }\end{array}$ & $\begin{array}{l}\text { Value } \\
\text { (3) }\end{array}$ & $\begin{array}{l}\text { Rank } \\
\text { (4) }\end{array}$ & $\begin{array}{l}\text { Value } \\
\text { (5) }\end{array}$ & $\begin{array}{l}\text { Rank } \\
(6)\end{array}$ & $\begin{array}{l}\text { Value } \\
(7)\end{array}$ & $\begin{array}{l}\text { Rank } \\
(8)\end{array}$ \\
\hline Victoria & 0.168 & 1 & 0.162 & 1 & 0.113 & 1 & 0.057 & 3 \\
\hline Vancouver & 0.131 & 2 & 0.126 & 2 & 0.078 & 3 & 0.040 & 5 \\
\hline Kelowna & 0.108 & 3 & 0.102 & 3 & 0.083 & 2 & 0.059 & 2 \\
\hline Abbotsford & 0.055 & 4 & 0.049 & 6 & 0.045 & 4 & 0.001 & 15 \\
\hline Toronto & 0.048 & 5 & 0.074 & 4 & 0.039 & 7 & 0.025 & 7 \\
\hline Calgary & 0.040 & 6 & -0.036 & 21 & 0.004 & 14 & -0.003 & 16 \\
\hline Montreal & 0.040 & 7 & 0.060 & 5 & -0.020 & 22 & 0.011 & 13 \\
\hline Sherbrooke & 0.016 & 8 & 0.037 & 7 & -0.018 & 19 & 0.012 & 12 \\
\hline Ottawa-Hull & 0.010 & 9 & 0.034 & 8 & -0.003 & 16 & 0.013 & 11 \\
\hline $\begin{array}{l}\text { British } \\
\text { Columbia, } \\
\text { non-CMA }\end{array}$ & 0.008 & . & 0.002 & . & 0.020 & . & -0.024 & . \\
\hline Barrie & 0.006 & 10 & 0.032 & 9 & 0.039 & 6 & 0.052 & 4 \\
\hline Halifax & 0.005 & 11 & -0.024 & 19 & 0.034 & 9 & 0.060 & 1 \\
\hline Peterborough & 0.004 & 12 & 0.030 & 10 & 0.040 & 5 & 0.020 & 8 \\
\hline Quebec & 0.003 & 13 & 0.024 & 14 & -0.035 & 26 & 0.020 & 10 \\
\hline Kingston & 0.002 & 14 & 0.028 & 11 & 0.037 & 8 & 0.020 & 9 \\
\hline
\end{tabular}


TABLE A1

(Continued)

\begin{tabular}{|c|c|c|c|c|c|c|c|c|}
\hline & \multicolumn{2}{|c|}{ Base QOL } & \multicolumn{2}{|c|}{$\begin{array}{l}\text { Transfer-adjusted } \\
\text { QOL }\end{array}$} & \multicolumn{2}{|c|}{$\begin{array}{l}\text { Non-housing } \\
\text { cost-adjusted } \\
\text { QOL }\end{array}$} & \multicolumn{2}{|c|}{$\begin{array}{l}\text { Rent-adjusted } \\
\text { QOL }\end{array}$} \\
\hline & $\begin{array}{l}\text { Value } \\
\text { (1) }\end{array}$ & $\begin{array}{l}\text { Rank } \\
\text { (2) }\end{array}$ & $\begin{array}{l}\text { Value } \\
\text { (3) }\end{array}$ & $\begin{array}{l}\text { Rank } \\
\text { (4) }\end{array}$ & $\begin{array}{l}\text { Value } \\
\text { (5) }\end{array}$ & $\begin{array}{l}\text { Rank } \\
\text { (6) }\end{array}$ & $\begin{array}{l}\text { Value } \\
\text { (7) }\end{array}$ & $\begin{array}{l}\text { Rank } \\
(8)\end{array}$ \\
\hline Hamilton & 0.001 & 15 & 0.027 & 12 & 0.023 & 10 & -0.009 & 20 \\
\hline Guelph & -0.002 & 16 & 0.024 & 13 & 0.020 & 11 & -0.004 & 18 \\
\hline Edmonton & -0.018 & 17 & -0.094 & 28 & -0.019 & 21 & -0.005 & 19 \\
\hline Kitchener & -0.028 & 18 & -0.002 & 15 & 0.003 & 15 & -0.012 & 21 \\
\hline Brantford & -0.033 & 19 & -0.007 & 16 & 0.013 & 12 & -0.017 & 24 \\
\hline $\begin{array}{l}\text { St. Catharines- } \\
\text { Niagara }\end{array}$ & -0.035 & 20 & -0.009 & 17 & 0.010 & 13 & -0.013 & 22 \\
\hline $\begin{array}{l}\text { Prince Edward } \\
\text { Island }\end{array}$ & -0.036 & . & -0.071 & . & 0.024 & . & 0.049 & . \\
\hline $\begin{array}{l}\text { Alberta, } \\
\text { non-CMA }\end{array}$ & -0.043 & . & -0.118 & . & -0.024 & . & -0.009 & . \\
\hline Oshawa & -0.044 & 21 & -0.018 & 18 & -0.018 & 18 & -0.023 & 27 \\
\hline $\begin{array}{l}\text { Ontario, } \\
\text { non-CMA }\end{array}$ & -0.045 & . & -0.019 & . & 0.011 & . & -0.030 & . \\
\hline Saskatoon & -0.050 & 22 & -0.107 & 30 & -0.032 & 25 & 0.005 & 14 \\
\hline Moncton & -0.053 & 23 & -0.090 & 26 & -0.018 & 20 & 0.033 & 6 \\
\hline Winnipeg & -0.054 & 24 & -0.093 & 27 & -0.047 & 28 & -0.003 & 17 \\
\hline London & -0.057 & 25 & -0.031 & 20 & -0.007 & 17 & -0.022 & 26 \\
\hline $\begin{array}{l}\text { Yukon } \\
\text { Territory }\end{array}$ & -0.058 & . & -0.246 & . & -0.058 & . & -0.046 & . \\
\hline $\begin{array}{l}\text { Quebec, } \\
\text { non-CMA }\end{array}$ & -0.064 & . & -0.043 & . & -0.065 & . & -0.041 & . \\
\hline Trois-Rivières & -0.079 & 26 & -0.058 & 22 & -0.085 & 32 & -0.045 & 29 \\
\hline St. John’s & -0.086 & 27 & -0.155 & 33 & -0.029 & 24 & -0.021 & 25 \\
\hline Regina & -0.086 & 28 & -0.143 & 32 & -0.064 & 31 & -0.014 & 23 \\
\hline Sudbury & -0.088 & 29 & -0.062 & 23 & -0.028 & 23 & -0.050 & 30 \\
\hline $\begin{array}{l}\text { Nova Scotia, } \\
\text { non-CMA }\end{array}$ & -0.089 & . & -0.118 & . & -0.002 & . & 0.006 & . \\
\hline $\begin{array}{l}\text { Chicoutimi- } \\
\text { Jonquière }\end{array}$ & -0.095 & 30 & -0.074 & 24 & -0.098 & 33 & -0.058 & 31 \\
\hline Saint John & -0.106 & 31 & -0.143 & 31 & -0.051 & 29 & -0.041 & 28 \\
\hline $\begin{array}{l}\text { New } \\
\text { Brunswick, } \\
\text { non-CMA }\end{array}$ & -0.106 & . & -0.143 & . & -0.039 & . & -0.006 & . \\
\hline Windsor & -0.112 & 32 & -0.085 & 25 & -0.054 & 30 & -0.072 & 33 \\
\hline $\begin{array}{l}\text { Northwest } \\
\text { Territory }\end{array}$ & -0.115 & . & -0.321 & . & -0.115 & . & -0.138 & . \\
\hline $\begin{array}{l}\text { Manitoba, } \\
\text { non-CMA }\end{array}$ & -0.119 & . & -0.158 & . & -0.068 & . & -0.048 & . \\
\hline Thunder Bay & -0.125 & 33 & -0.099 & 29 & -0.044 & 27 & -0.063 & 32 \\
\hline $\begin{array}{l}\text { Saskatchewan, } \\
\text { non-CMA }\end{array}$ & -0.153 & . & -0.210 & . & -0.076 & . & -0.028 & . \\
\hline $\begin{array}{l}\text { Newfoundland, } \\
\text { non-CMA }\end{array}$ & -0.228 & . & -0.297 & . & -0.103 & . & -0.070 & . \\
\hline $\begin{array}{l}\text { Nunavut } \\
\text { Territory }\end{array}$ & -0.309 & . & -0.590 & . & -0.309 & . & -0.387 & . \\
\hline
\end{tabular}


TABLE A2

Alternative total value measures using adjustments

\begin{tabular}{|c|c|c|c|c|c|c|c|c|}
\hline & \multicolumn{2}{|c|}{ Base value } & \multicolumn{2}{|c|}{$\begin{array}{l}\text { Transfer-adjusted } \\
\text { value }\end{array}$} & \multicolumn{2}{|c|}{$\begin{array}{l}\text { Non-housing } \\
\text { cost-adjusted } \\
\text { value }\end{array}$} & \multicolumn{2}{|c|}{$\begin{array}{l}\text { Rent-adjusted } \\
\text { value }\end{array}$} \\
\hline & $\begin{array}{l}\text { Value } \\
\text { (1) }\end{array}$ & $\begin{array}{l}\text { Rank } \\
\text { (2) }\end{array}$ & $\begin{array}{l}\text { Value } \\
\text { (3) }\end{array}$ & $\begin{array}{l}\text { Rank } \\
\text { (4) }\end{array}$ & $\begin{array}{l}\text { Value } \\
\text { (5) }\end{array}$ & $\begin{array}{l}\text { Rank } \\
\text { (6) }\end{array}$ & $\begin{array}{l}\text { Value } \\
\text { (7) }\end{array}$ & $\begin{array}{l}\text { Rank } \\
(8)\end{array}$ \\
\hline Vancouver & 0.179 & 1 & 0.174 & 1 & 0.126 & 1 & 0.088 & 2 \\
\hline Victoria & 0.179 & 2 & 0.173 & 2 & 0.125 & 2 & 0.068 & 3 \\
\hline Toronto & 0.115 & 3 & 0.141 & 3 & 0.105 & 3 & 0.092 & 1 \\
\hline Calgary & 0.098 & 4 & 0.023 & 11 & 0.063 & 5 & 0.056 & 5 \\
\hline Kelowna & 0.091 & 5 & 0.085 & 4 & 0.066 & 4 & 0.042 & 6 \\
\hline Montreal & 0.058 & 6 & 0.079 & 6 & -0.002 & 15 & 0.030 & 9 \\
\hline Ottawa-Hull & 0.056 & 7 & 0.080 & 5 & 0.043 & 6 & 0.059 & 4 \\
\hline Abbotsford & 0.049 & 8 & 0.043 & 9 & 0.039 & 9 & -0.005 & 16 \\
\hline Guelph & 0.020 & 9 & 0.046 & 7 & 0.042 & 7 & 0.018 & 10 \\
\hline Hamilton & 0.020 & 10 & 0.046 & 8 & 0.042 & 8 & 0.010 & 11 \\
\hline Oshawa & 0.012 & 11 & 0.038 & 10 & 0.038 & 10 & 0.033 & 7 \\
\hline Edmonton & -0.006 & 12 & -0.082 & 24 & -0.007 & 17 & 0.007 & 13 \\
\hline Kitchener & -0.008 & 13 & 0.019 & 12 & 0.024 & 11 & 0.009 & 12 \\
\hline Quebec & -0.009 & 14 & 0.011 & 13 & -0.048 & 23 & 0.007 & 14 \\
\hline Barrie & -0.016 & 15 & 0.010 & 14 & 0.017 & 12 & 0.030 & 8 \\
\hline $\begin{array}{l}\text { British } \\
\text { Columbia, } \\
\text { non-CMA }\end{array}$ & -0.018 & . & -0.024 & & -0.005 & . & -0.050 & \\
\hline Kingston & -0.023 & 16 & 0.003 & 15 & 0.012 & 13 & -0.005 & 17 \\
\hline Peterborough & -0.027 & 17 & -0.001 & 16 & 0.009 & 14 & -0.010 & 18 \\
\hline $\begin{array}{l}\text { Northwest } \\
\text { Territory }\end{array}$ & -0.028 & . & -0.233 & & -0.028 & . & -0.050 & . \\
\hline Sherbrooke & -0.029 & 18 & -0.009 & 17 & -0.063 & 24 & -0.033 & 21 \\
\hline $\begin{array}{l}\text { Yukon } \\
\text { Territory }\end{array}$ & -0.047 & . & -0.235 & & -0.047 & . & -0.036 & . \\
\hline $\begin{array}{l}\text { St. Catharines- } \\
\text { Niagara }\end{array}$ & -0.051 & 19 & -0.024 & 18 & -0.005 & 16 & -0.028 & 20 \\
\hline Brantford & -0.055 & 20 & -0.028 & 19 & -0.008 & 18 & -0.038 & 22 \\
\hline Halifax & -0.057 & 21 & -0.086 & 25 & -0.028 & 21 & -0.002 & 15 \\
\hline London & -0.062 & 22 & -0.036 & 20 & -0.012 & 19 & -0.027 & 19 \\
\hline $\begin{array}{l}\text { Alberta, } \\
\text { non-CMA }\end{array}$ & -0.066 & . & -0.142 & . & -0.048 & . & -0.033 & . \\
\hline Windsor & -0.080 & 23 & -0.054 & 21 & -0.023 & 20 & -0.040 & 23 \\
\hline $\begin{array}{l}\text { Ontario, } \\
\text { non-CMA }\end{array}$ & -0.084 & . & -0.058 & . & -0.028 & . & -0.070 & . \\
\hline Sudbury & -0.091 & 24 & -0.065 & 22 & -0.031 & 22 & -0.053 & 25 \\
\hline Trois-Rivières & -0.102 & 25 & -0.081 & 23 & -0.109 & 30 & -0.068 & 29 \\
\hline $\begin{array}{l}\text { Chicoutimi- } \\
\text { Jonquière }\end{array}$ & -0.110 & 26 & -0.089 & 26 & -0.113 & 31 & -0.073 & 30 \\
\hline Winnipeg & -0.114 & 27 & -0.153 & 28 & -0.107 & 29 & -0.063 & 28 \\
\hline Saskatoon & -0.117 & 28 & -0.174 & 30 & -0.099 & 26 & -0.062 & 27 \\
\hline $\begin{array}{l}\text { Quebec, } \\
\text { non-CMA }\end{array}$ & -0.123 & . & -0.103 & . & -0.125 & . & -0.101 & . \\
\hline Regina & -0.128 & 29 & -0.185 & 31 & -0.105 & 28 & -0.055 & 26 \\
\hline Moncton & -0.137 & 30 & -0.174 & 29 & -0.101 & 27 & -0.050 & 24 \\
\hline Thunder Bay & -0.154 & 31 & -0.128 & 27 & -0.073 & 25 & -0.092 & 31 \\
\hline
\end{tabular}


TABLE A2

(Continued)

\begin{tabular}{|c|c|c|c|c|c|c|c|c|}
\hline & \multicolumn{2}{|c|}{ Base value } & \multicolumn{2}{|c|}{$\begin{array}{l}\text { Transfer-adjusted } \\
\text { value }\end{array}$} & \multicolumn{2}{|c|}{$\begin{array}{l}\text { Non-housing } \\
\text { cost-adjusted } \\
\text { value }\end{array}$} & \multicolumn{2}{|c|}{$\begin{array}{l}\text { Rent-adjusted } \\
\text { value }\end{array}$} \\
\hline & $\begin{array}{l}\text { Value } \\
\text { (1) }\end{array}$ & $\begin{array}{l}\text { Rank } \\
\text { (2) }\end{array}$ & $\begin{array}{l}\text { Value } \\
\text { (3) }\end{array}$ & $\begin{array}{l}\text { Rank } \\
\text { (4) }\end{array}$ & $\begin{array}{l}\text { Value } \\
\text { (5) }\end{array}$ & $\begin{array}{l}\text { Rank } \\
\text { (6) }\end{array}$ & $\begin{array}{l}\text { Value } \\
\text { (7) }\end{array}$ & $\begin{array}{l}\text { Rank } \\
\text { (8) }\end{array}$ \\
\hline St. John's & -0.175 & 32 & -0.244 & 33 & -0.118 & 32 & -0.109 & 32 \\
\hline $\begin{array}{l}\text { Prince Edward } \\
\text { Island }\end{array}$ & -0.186 & . & -0.221 & . & -0.125 & - & -0.100 & . \\
\hline Saint John & -0.189 & 33 & -0.226 & 32 & -0.135 & 33 & -0.125 & 33 \\
\hline $\begin{array}{l}\text { Nunavut } \\
\text { Territory }\end{array}$ & -0.225 & . & -0.506 & . & -0.225 & . & -0.303 & . \\
\hline $\begin{array}{l}\text { New } \\
\text { Brunswick, } \\
\text { non-CMA }\end{array}$ & -0.233 & . & -0.270 & . & -0.166 & . & -0.133 & . \\
\hline $\begin{array}{l}\text { Nova Scotia, } \\
\text { non-CMA }\end{array}$ & -0.237 & . & -0.266 & . & -0.150 & . & -0.142 & . \\
\hline $\begin{array}{l}\text { Manitoba, } \\
\text { non-CMA }\end{array}$ & -0.251 & . & -0.290 & . & -0.200 & . & -0.180 & . \\
\hline $\begin{array}{c}\text { Saskatchewan, } \\
\text { non-CMA }\end{array}$ & -0.299 & . & -0.356 & . & -0.222 & . & -0.174 & . \\
\hline $\begin{array}{l}\text { Newfoundland, } \\
\text { non-CMA }\end{array}$ & -0.375 & . & -0.445 & . & -0.251 & . & -0.218 & . \\
\hline
\end{tabular}

TABLE A3

Additional statistics by CMA

\begin{tabular}{llllr}
\hline CMA & $\begin{array}{l}\text { Union coverage } \\
\text { rate }\end{array}$ & $\begin{array}{l}\text { Employment } \\
\text { rate }\end{array}$ & $\begin{array}{l}\text { Fraction who } \\
\text { work in CMA } \\
\text { of residence }\end{array}$ & $\begin{array}{l}\text { Log CPI } \\
\text { non-housing }\end{array}$ \\
\hline St. John's & 0.401 & 0.778 & 0.974 & -0.003 \\
Halifax & 0.346 & 0.818 & 0.980 & 0.010 \\
Moncton & 0.310 & 0.845 & 0.943 & -0.014 \\
Saint John & 0.342 & 0.812 & 0.973 & -0.014 \\
Chicoutimi-Jonquière & 0.541 & 0.751 & 0.951 & -0.053 \\
Quebec & 0.492 & 0.835 & 0.956 & -0.053 \\
Sherbrooke & 0.499 & 0.789 & 0.885 & -0.053 \\
Trois-Rivières & 0.542 & 0.791 & 0.850 & -0.053 \\
Montreal & 0.377 & 0.788 & 0.975 & -0.053 \\
Ottawa-Hull & 0.454 & 0.825 & 0.984 & 0.037 \\
Kingston & 0.460 & 0.783 & 0.935 & 0.037 \\
Peterborough & 0.430 & 0.841 & 0.834 & 0.037 \\
Oshawa & 0.425 & 0.841 & 0.566 & 0.037 \\
Toronto & 0.239 & 0.813 & 0.979 & 0.037 \\
Hamilton & 0.328 & 0.822 & 0.737 & 0.037 \\
St. Catharines-Niagara & 0.348 & 0.812 & 0.897 & 0.037 \\
Kitchener & 0.296 & 0.843 & 0.848 & 0.037 \\
Brantford & 0.312 & 0.824 & 0.721 & 0.037 \\
Guelph & 0.295 & 0.867 & 0.717 & 0.037 \\
London & 0.333 & 0.827 & 0.936 & 0.037 \\
\hline
\end{tabular}


TABLE A3

(Continued)

\begin{tabular}{llllr}
\hline CMA & $\begin{array}{l}\text { Union coverage } \\
\text { rate }\end{array}$ & $\begin{array}{l}\text { Employment } \\
\text { rate }\end{array}$ & $\begin{array}{l}\text { Fraction who } \\
\text { work in CMA } \\
\text { of residence }\end{array}$ & $\begin{array}{l}\text { Log CPI } \\
\text { non-housing }\end{array}$ \\
\hline Windsor & 0.421 & 0.775 & 0.953 & 0.037 \\
Barrie & 0.276 & 0.877 & 0.595 & 0.037 \\
Sudbury & 0.456 & 0.771 & 0.977 & 0.037 \\
Thunder Bay & 0.497 & 0.797 & 0.976 & 0.037 \\
Winnipeg & 0.423 & 0.837 & 0.973 & -0.041 \\
Regina & 0.444 & 0.855 & 0.981 & -0.029 \\
Saskatoon & 0.436 & 0.844 & 0.974 & -0.029 \\
Calgary & 0.228 & 0.847 & 0.982 & -0.004 \\
Edmonton & 0.298 & 0.821 & 0.977 & -0.004 \\
Kelowna & 0.253 & 0.830 & 0.956 & 0.009 \\
Abbotsford & 0.343 & 0.808 & 0.644 & 0.009 \\
Vancouver & 0.340 & 0.792 & 0.986 & 0.009 \\
Victoria & 0.384 & 0.825 & 0.983 & 0.009 \\
Newfoundland, non-CMA & 0.438 & 0.619 & & -0.003 \\
Prince Edward Island & 0.377 & 0.798 & & -0.004 \\
Nova Scotia, non-CMA & 0.345 & 0.734 & & 0.010 \\
New Brunswick, non-CMA & 0.338 & 0.724 & & -0.014 \\
Quebec, non-CMA & 0.479 & 0.779 & & -0.053 \\
Ontario, non-CMA & 0.389 & 0.808 & & 0.037 \\
Manitoba, non-CMA & 0.436 & 0.839 & & -0.041 \\
Saskatchewan, non-CMA & 0.367 & 0.838 & & -0.029 \\
Alberta, non-CMA & 0.257 & 0.848 & & -0.004 \\
British Columbia, non-CMA & 0.402 & 0.790 & & 0.009 \\
\hline
\end{tabular}

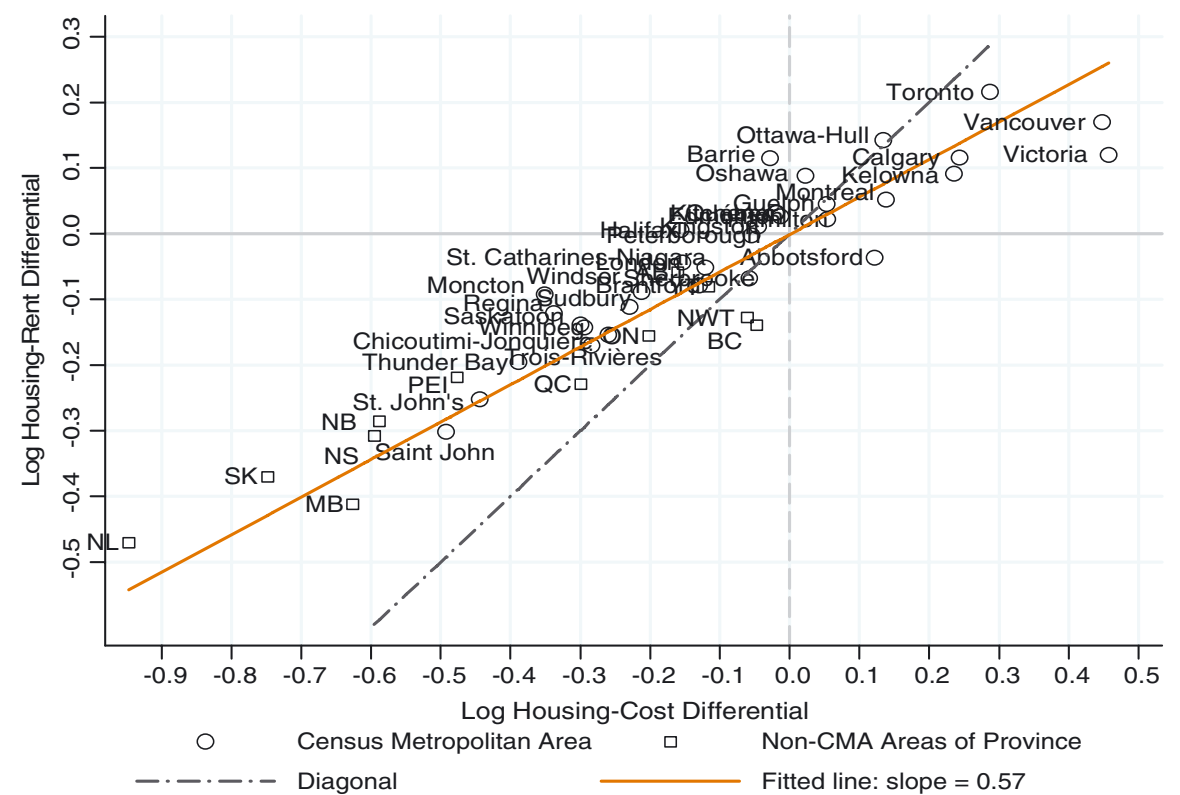

FIGURE A1 Housing costs versus wage levels across CMAs 


\section{References}

Albouy, David (2008a) 'Are big cities bad places to live? Estimating quality of life across metropolitan areas.' NBER Working Paper No. 14472

- (2008b) 'The wage gap between francophones and anglophones: a Canadian perspective, 1970-2000.' Canadian Journal of Economics 41, 1211-38

- (2009a) 'The unequal geographic burden of federal taxation.' Journal of Political Economy 117, 635-67

- (2009b) 'What are cities worth? Land rents, local productivity, and the value of amenities.' NBER Working Paper 1498

- (2012) 'Evaluating the efficiency and equity of federal fiscal equalization.' Journal of Public Economics 96, 824-39

Albouy, David, and Bert Lue (2011) 'Driving to opportunity: local wages, commuting, and sub-metropolitan quality of life.' Mimeo

Beeson, Patricia E. (1991) 'Amenities and regional differences in returns to worker characteristics.' Journal of Urban Economics 30, 224-41

Beeson, Patricia E., and Randall W. Eberts (1989) 'Identifying productivity and amenity effects in interurban wage differentials.' Review of Economics and Statistics 71, 443-52

Bernard, André, Ross Finnie, and Benoît St-Jean (2008) 'Interprovincial mobility and earnings.' In Perspectives on Labour and Income. Ottawa: Statistics Canada

Blomquist, Glenn C., Mark C. Berger, and John P. Hoehn (1988) 'New estimates of quality of life in urban areas.' American Economic Review 78, 89-107

Chen, Yu, and Stuart Rosenthal (2008) 'Local amenities and life-cycle migration: do people move for jobs or fun?' Journal of Urban Economics 64, 519-37

Coulombe, Serge (2000) 'New evidence of convergence across Canadian provinces: the role of urbanization.' Regional Studies 34, 713-25

Coulombe, Serge, and Frank C. Lee (1995) 'Convergence across Canadian provinces, 1961 to 1991.' Canadian Journal of Economics 28, 886-98

Fang, Tony, and Anil Verma (2002) 'Union wage premium.' In Perspectives on Labour and Income. Ottawa: Statistics Canada

Gabriel, Stuart, and Stuart Rosenthal (2004) 'Quality of the business environment versus quality of life: do firms and households like the same cities?' Review of Economics and Statistics 86, 438-44

Giannias, Dimitrios A. (1998) 'A quality of life based ranking of Canadian cities.' Urban Studies 35, 2241-51

Glaeser, Edward L., and David C. Maré (2001) 'Cities and Skills.' Journal of Labor Economics 19, 316-42

Gyourko, Joseph, and Joseph Tracy (1991) 'The structure of local public finance and the quality of life.' Journal of Political Economy 99, 774-806

Malpezzi, Stephen, Gregory Chun, and Richard Green (1998) 'New place to place housing price indexes for U.S. metropolitan areas, and their determinants: an application of housing indicators.' Real Estate Economics 26, 235-74

Ottaviano, Gianmarco, and Giovanni Peri (2012) 'Rethinking the effects of immigration on wages.' Journal of the European Economic Association 10, 152-97

Peiser, Richard, and Lawrence Smith (1985) 'Homeownership returns, tenure choice and inflation.' Real Estate Economics 13, 343-60

Roback, Jennifer (1982) 'Wages, rents, and the quality of life.' Journal of Political Economy 90, 1257-78

- (1988) 'Wages, rents, and amenities: differences among workers and regions.' Economic Inquiry 26, 23-41 
Rosen, Sherwin (1979) 'Wages-based indexes of urban quality of life.' In Current Issues in Urban Economics, ed. P. Mieszkowski and M. Straszheim. Baltimore, MD: Johns Hopkins University Press

Shapiro, Jesse (2006) 'Smart cities: quality of life, productivity, and the growth effects of human capital.' Review of Economics and Statistics 88, 324-35

Statistics Canada (2008) New Housing Price Index (NHPI). Last accessed 12 February 2013. http://www23.statcan.gc.ca/imdb/p2SV.pl?Function=getSurvey\& SurvId=32608\&SurvVer=2\&InstaId $=32633 \&$ InstaVer $=114 \&$ SDDS $=2310 \&$ lang=en $\& \& \mathrm{adm}=8 \&$ dis $=2$

Tal, Benjamin (2011) 'Canadian housing prices beware of the average.' CIBC Consumer Watch, 7 July 2011

Warman, Casey (2007) 'Ethnic enclaves and immigrant earnings growth.' Canadian Journal of Economics 40, 401-22

Violante, Giovanni (2008) 'Skill-biased technical change.' In New Palgrave Dictionary of Economics. 2nd ed. New York: Palgrave Macmillan 